\title{
Comparative efficacy of long-acting muscarinic antagonist monotherapies in COPD: a systematic review and network meta-analysis
}

This article was published in the following Dove Press journal:

International Journal of COPD

16 November 2015

Number of times this article has been viewed

\author{
Afisi Segun Ismaila ${ }^{1,2}$ \\ Eline L Huisman ${ }^{3}$ \\ Yogesh Suresh Punekar ${ }^{4}$ \\ Andreas Karabis ${ }^{3}$ \\ 'Value Evidence and Outcomes, \\ GlaxoSmithKline, Research Triangle \\ Park, NC, USA; ${ }^{2}$ Clinical Epidemiology \\ and Biostatistics, McMaster University, \\ Hamilton, ON, Canada; ${ }^{3}$ Real World \\ Strategy and Analytics, Mapi \\ Group, Houten, the Netherlands; \\ ${ }^{4}$ Value Evidence and Outcomes, \\ GlaxoSmithKline, Uxbridge, UK
}

Background: Randomized, controlled trials comparing long-acting muscarinic antagonist (LAMA) efficacy in COPD are limited. This network meta-analysis (NMA) assessed the relative efficacy of tiotropium $18 \mu \mathrm{g}$ once-daily (OD) and newer agents (aclidinium $400 \mu \mathrm{g}$ twice-daily, glycopyrronium $50 \mu \mathrm{g} \mathrm{OD}$, and umeclidinium $62.5 \mu \mathrm{g}$ OD).

Methods: A systematic literature review identified randomized, controlled trials of adult COPD patients receiving LAMAs. A NMA within a Bayesian framework examined change from baseline in trough forced expiratory volume in 1 second $\left(\mathrm{FEV}_{1}\right)$, transitional dyspnea index focal score, St George's Respiratory Questionnaire score, and rescue medication use.

Results: Twenty-four studies $(\mathrm{n}=21,311)$ compared LAMAs with placebo/each other. Aclidinium, glycopyrronium, tiotropium, and umeclidinium, respectively, demonstrated favorable results versus placebo, for change from baseline (95\% credible interval) in 12-week trough $\mathrm{FEV}_{1}$ (primary endpoint: $101.40 \mathrm{~mL}$ [77.06-125.60]; $117.20 \mathrm{~mL}$ [104.50-129.90]; $114.10 \mathrm{~mL}$ [103.10-125.20]; $136.70 \mathrm{~mL}$ [104.20-169.20]); 24-week trough $\mathrm{FEV}_{1}(128.10 \mathrm{~mL}$ [84.10172.00]; 135.80 mL [123.10-148.30]; $106.40 \mathrm{~mL}$ [95.45-117.30]; $115.00 \mathrm{~mL}$ [74.51-155.30]); 24-week St George's Respiratory Questionnaire score ( -4.60 [ -6.76 to -2.54$] ;-3.14[-3.83$ to -2.45$] ;-2.43$ [ -2.92 to -1.93$] ;-4.69[-7.05$ to -2.31$]) ; 24$-week transitional dyspnea index score (1.00 [0.41-1.59]; 1.01 [0.79-1.22]; 0.82 [0.62-1.02]; 1.00 [0.49-1.51]); and 24-week rescue medication use (data not available; $-0.41 \mathrm{puffs} /$ day $[-0.62$ to -0.20$] ;-0.52 \mathrm{puffs} /$ day [-0.74 to -0.30$] ;-0.30$ puffs/day [ -0.81 to 0.21$]$ ). For 12 -week trough $\mathrm{FEV}_{1}$, differences in change from baseline ( $95 \%$ credible interval) were $-12.8 \mathrm{~mL}$ ( -39.39 to 13.93$)$, aclidinium versus tiotropium; $3.08 \mathrm{~mL}$ ( -7.58 to 13.69 ), glycopyrronium versus tiotropium; $22.58 \mathrm{~mL}$ ( -11.58 to 56.97), umeclidinium versus tiotropium; $15.90 \mathrm{~mL}$ ( -11.60 to 43.15$)$, glycopyrronium versus aclidinium; $35.40 \mathrm{~mL}$ (-5.06 to 76.07), umeclidinium versus aclidinium; and $19.50 \mathrm{~mL}$ (-15.30 to 54.38), umeclidinium versus glycopyrronium. Limitations included inhaler-related factors and safety; longer-term outcomes were not considered.

Conclusion: The new LAMAs studied had at least comparable efficacy to tiotropium, the established class standard. Choice should depend on physician's and patient's preference.

Keywords: anticholinergics, muscarinic antagonist, bronchodilator, systematic review, meta-analysis

\section{Introduction}

The overarching goals for the management of COPD include prevention of further disease progression, symptom relief, reduction in exacerbations, treatment of complications (eg, infections), and the maintenance or improvement of overall health status. ${ }^{1}$ Treatment options for COPD depend on symptom burden and exacerbation risk, but bronchodilators are a cornerstone of therapy. Long-acting muscarinic antagonists
Correspondence: Afisi Segun Ismaila Value Evidence and Outcomes, GlaxoSmithKline, 5 Moore Drive, PO Box 13398, Research Triangle Park, NC 27709-3398, USA

$\mathrm{Tel}+\mathrm{I} 9193158229$

Email afisi.s.ismaila@gsk.com (c) (i) (5) 2015 Ismaila et al. This work is published by Dove Medical Press Limited, and licensed under Creative Commons Attribution - Non Commercial (unported, v3.0) BY LC License. The full terms of the License are available at http://creativecommons.org/licenses/lby-nc/3.0/. Non-commercial uses of the work are permitted without any further permite how to request permission may be found at: http://www.dovepress.com/permissions.php 
(LAMAs) are recommended for patients in Global Initiative for Chronic Obstructive Lung Disease (GOLD) groups A to D. ${ }^{1}$ LAMAs are associated with improved lung function, improved quality of life, and reduced exacerbations. ${ }^{2,3}$

Until 2012, tiotropium bromide was the only LAMA widely available for the treatment of COPD. ${ }^{3-5}$ Tiotropium is a once-daily (OD) treatment, and has been widely prescribed for COPD. However, several new LAMAs have since been introduced, including aclidinium bromide (twice-daily [BD] for COPD maintenance) and glycopyrronium bromide (OD for COPD maintenance), which could be used as alternatives to tiotropium. ${ }^{6-9}$ Umeclidinium bromide has been the most recent addition; this is a OD inhaled LAMA approved for COPD maintenance therapy in adults in the EU, USA, and several other countries. Compared with placebo, umeclidinium OD (metered dose $62.5 \mu \mathrm{g}$, delivered dose $55 \mu \mathrm{g}$ ) significantly improved lung function, dyspnea, and health status over 12 weeks in a randomized study of 246 patients. ${ }^{9}$ With this new addition to the LAMA class, there is a need to understand the relative comparative efficacy of the available agents.

Primary comparative efficacy data from randomized controlled trials for newer LAMAs are limited. With the introduction of new agents, such as umeclidinium, it is often not feasible to conduct clinical trials to compare the new treatment against all alternative agents in clinical trials to determine relative efficacy. Accordingly, there are no published direct head-to-head comparisons on the clinical efficacy between all LAMAs. Therefore, alternative methodologies need to be employed to better inform health care practitioners of the anticipated relative efficacy for important clinical endpoints. A number of network meta-analyses (NMAs) have been published in recent years, comparing LAMAs (tiotropium and glycopyrronium) with other COPD therapies, ${ }^{10}$ and aclidinium versus glycopyrronium and tiotropium. ${ }^{11}$ However, since the introduction of a new treatment option (umeclidinium), further analyses are needed. A systematic literature review and Bayesian NMA was undertaken to assess the relative efficacy of aclidinium, glycopyrronium, tiotropium, and umeclidinium for the treatment of COPD.

\section{Methods}

\section{Study objectives}

The primary objective of this study (GSK study number: 201280) ${ }^{12}$ was to assess the relative efficacy of all LAMAs available in the market at the licensed doses, namely: aclidinium $400 \mu \mathrm{g}$ BD (hereafter referred to as aclidinium), glycopyrronium $50 \mu \mathrm{g}$ OD (glycopyrronium), tiotropium $18 \mu \mathrm{g}$ OD (tiotropium), and umeclidinium 62.5 $\mu \mathrm{g}$ OD (umeclidinium), by means of lung function (difference in change from baseline for trough forced expiratory volume in 1 second $\left.\left[\mathrm{FEV}_{1}\right]\right)$ at 12 weeks. The doses of each of the four LAMAs chosen for this NMA were the only approved doses for the dry powder inhaler formulations. Other formulations such as tiotropium $5 \mu \mathrm{g}$ OD via a soft mist device, which is considered as equivalent to $18 \mu \mathrm{g}$ via the Handihaler, or alternative BD glycopyrronium/glycopyrrolate investigational formulations have not been included. Secondary objectives were to assess the relative efficacy of the LAMA for the following endpoints: 1) difference in change from baseline for trough $\mathrm{FEV}_{1}$ (at 24 weeks); 2) difference in change from baseline in St George's Respiratory Questionnaire (SGRQ) total score (at 12 and 24 weeks); 3) differences in the transitional dyspnea index (TDI) focal score (at 12 and 24 weeks); and 4) differences in change in rescue medication use (mean number of puffs per day) (at 12 and 24 weeks). The 12- and 24-week time points used in our study were chosen to reflect the expected data availability; these are commonly used time intervals in COPD trials.

\section{Data sources}

A systematic review including a broad range of search terms following Preferred Reporting Items for Systematic reviews and Meta-Analyses (PRISMA) guidelines was performed. ${ }^{13}$ The following databases were searched: MEDLINE (through Ovid platform); MEDLINE In-Process (Ovid); EMBASE (Ovid); The Cochrane Database of Systematic Reviews (CDSR) and Cochrane Central Register of Controlled Trials (CENTRAL); Database of Abstracts of Reviews of Effects (DARE); and Health Technology Assessment (HTA) websites, HTA database and National Institute for Health Research (NIHR). The following clinical trial registries were searched: Clinicaltrials.gov; World Health Organization International Clinical Trials Registry Platform (WHO ICTRP); Current Controlled Trials; EU Clinical Trials Register (EU-CTR); Klinische Prüfungen PharmNet.Bund; and The International Prospective Register of Systematic Reviews (PROSPERO). The searches were performed on April 14, 2014-April 16, 2014, for studies in English and German language without time restrictions. Predefined search strategies were used (available in Table S1), tailored for each database.

\section{Inclusion criteria and study selection process for systematic literature review}

The relevance of each identified citation was assessed based on the title and abstract according to predefined selection criteria (Table S2). For the abstracts that met the selection 
criteria, available publications were obtained and evaluated using the full-text selection criteria. Studies (randomized, controlled trials) had to include adults with COPD reporting on at least one of: umeclidinium; aclidinium; tiotropium; glycopyrronium compared with each other or placebo. The outcomes examined were trough $\mathrm{FEV}_{1}$, TDI focal score, SGRQ score, and rescue medication. The time points of interest for all outcomes were 12 and 24 weeks, while outcomes between 8 and 16 weeks or 20 and 28 weeks were reported as proxy outcomes for 12 and 24 weeks, respectively. The selection was performed by two researchers independently and any discrepancies were resolved by consensus. The final selected citations were grouped per study.

\section{Data abstraction and quality assessment}

Key data from each eligible study were extracted, including study design (treatments, duration, inclusion/exclusion criteria, and background treatment) and patient characteristics (eg, age, sex, and lung function parameters; Table S3) into a data extraction form. Data extraction was performed by one researcher and verified by another researcher. Data of interest presented in graphs were extracted using DigitizeIT version 1.5 software (DigitizeIT, Braunschweig, Germany). The methodological and reporting quality of the included trials was assessed with a checklist based on the guidance by the Institute for Quality and Efficiency in Health Care. ${ }^{14}$ The risk of bias in each study was classified as "high" or "low" based on the following items: appropriate generation of a randomization sequence; adequate allocation concealment; blinding of patients, treating staff, and staff responsible for follow-up treatment; reporting of all relevant outcomes independent of results; no other aspects that could lead to bias. The results of the risk of bias assessment are presented in Table S4.

\section{Data synthesis}

The existence of a connected network of studies per outcome, as well as the study design and patient characteristics of the identified studies, was used to assess the feasibility of a valid NMA. ${ }^{15}$ The identified evidence was used to perform a NMA within a Bayesian framework to simultaneously synthesize the results of the included studies and to obtain relative treatment effects. ${ }^{16,17}$ A generalized linear model with normal likelihood distribution was used. ${ }^{18}$ Non-informative prior distributions of the relative treatment effects (normal distributions with zero mean and a variance of 10,000) were used as a widely accepted option for all outcomes of interest. The analysis was based on the difference between the least square mean at follow-up or the difference in change from baseline for the active treatment versus the comparator as well as the associated standard error (SE) of the difference. To assess the consistency of the network, the node splitting method was followed by separating and comparing direct and indirect evidence per outcome for each one of these three pairwise comparisons. ${ }^{19}$

For each outcome, a fixed- and a random-effects model was evaluated. The fixed-effects model assumed that the differences in true relative treatment effects across studies in the network of evidence were only due to differences in treatment comparisons (ie, that there was no variation in relative treatment effects for a particular pairwise comparison). The random-effects model assumed that differences in observed treatment effects across the studies in the network were not only caused by the different treatment comparisons, but that there was also heterogeneity in the relative effects for a particular type of comparison caused by factors that modify the relative treatment effect. With the NMA models used, the heterogeneity was assumed to be constant for every treatment comparison. Due to the relatively low number of studies, treatment-by-covariate interactions could not be incorporated into the models; instead, scenario analyses were developed to test the impact of certain studies on the relative treatment estimates.

The goodness of fit of each model to the data was assessed using the Deviance Information Criterion. ${ }^{20}$ The posterior densities for the outcomes of interest were estimated using the Markov Chain Monte Carlo simulations for each model. The results were based on 80,000 iterations on three chains, with a burn-in of 20,000 iterations. Convergence assessment was based on visual inspection of trace plots. Accuracy of the posterior estimates was assessed using the Monte Carlo error for each parameter (Monte Carlo error $<5 \%$ of the posterior standard deviation [SD]). Given the dataset used, the fixed-effects model was chosen over the random-effects model unless there was enough evidence to suggest that the random-effects model was substantially different (ie, Deviance Information Criterion value was lower and Monte Carlo error was not out of proportion). WinBUGS 1.4.3 statistical software was used for the analyses ${ }^{21}$ and the models were based on those defined by Dias et al (programs 7(b) and 8(a) in the Appendix of Dias et al). ${ }^{18}$

The NMA provided posterior distributions of the relative treatment effects between interventions for each outcome of interest. The posterior distributions were summarized with the median to reflect the most likely value of the estimate, and the 2.5 th and 97.5 th percentile to capture the $95 \%$ credible interval $(\mathrm{CrI}) .{ }^{18}$ The $95 \% \mathrm{CrI}$ represents the range of true underlying effects with $95 \%$ probability. For each endpoint, 
the probability that each treatment was better than a certain comparator was established.

If a study only reported mean differences without a measure of uncertainty (SE, SD, or confidence interval [CI]), the following steps were executed to impute SE values: 1) SD of the difference for each study reporting sufficient data were calculated by the formula SD of difference $=\mathrm{SE}$ of difference $\times$ square root of $\mathrm{N} ; 2$ ) the average $\mathrm{SD}$ of the trials in the network was calculated; 3 ) the average SD of the trials in the network is imputed for the trial that did not report a $\mathrm{SD} / \mathrm{SE} / 95 \% \mathrm{CI}$; or 4 ) the $\mathrm{SE}$ of the difference = average $\mathrm{SD} /$ square root of $\mathrm{N}$.

\section{Results}

\section{Search and selection results}

A total of 3,006 citations and 4,720 clinical trials were identified (Figure 1). After screening, 95 citations (publications and trials) reporting on 24 different trials with 21,311 patients were included in the analysis.

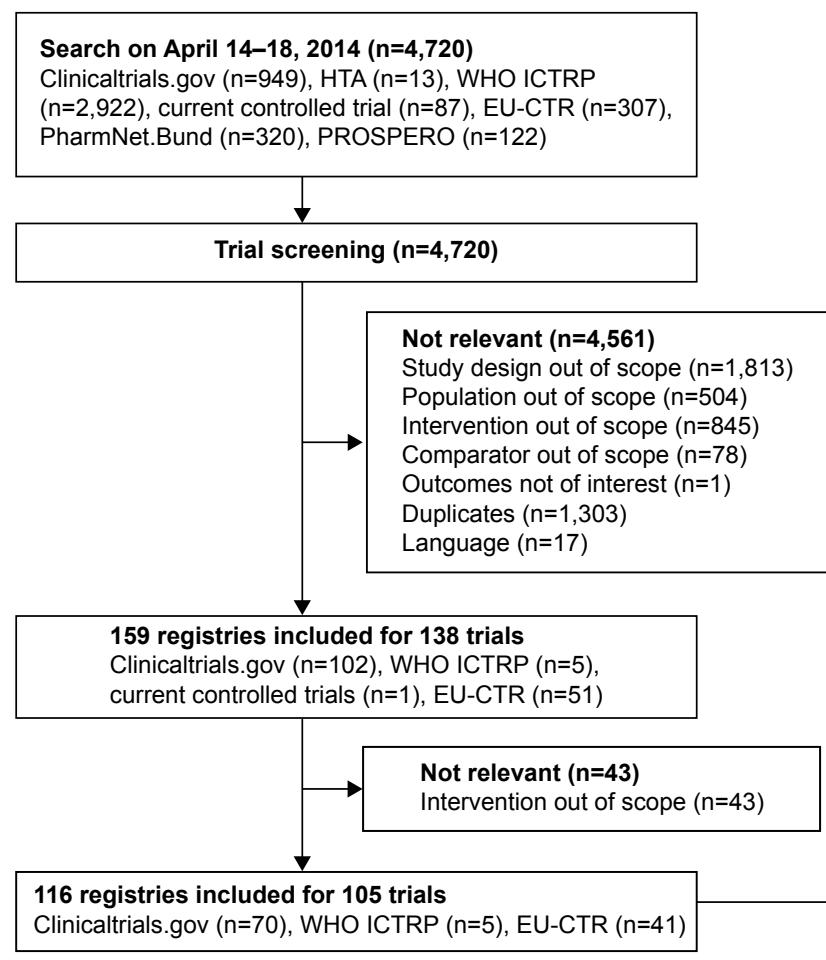

\section{Study characteristics}

All studies included in the analyses were parallel-group, multicenter, randomized, controlled trials and the number of patients randomized per arm ranged from $46^{22}$ to $3,006^{3}$ (Table 1). All trials were double blind, with the exception of one tiotropium trial that included tiotropium as an open-label arm. ${ }^{23}$ Inhaled corticosteroids were allowed in all the studies where information on inhaled corticosteroid background was reported. Long-acting $\beta_{2}$-agonist (LABA) background treatment was allowed in five tiotropium studies (LABA use at baseline ranged from $38 \%$ to $61 \%$ of the study arms, where data were available)..$^{3,4,24,25}$ Information on LABA use was missing in three studies, ${ }^{26-28}$ and was not allowed in the remaining studies.

\section{Patient characteristics}

Patient populations ranged from $49 \%$ to $99 \%$ male (Table 2 ), but the mean age was similar across the studies (mean range 60-67 years). Spirometry measures were generally

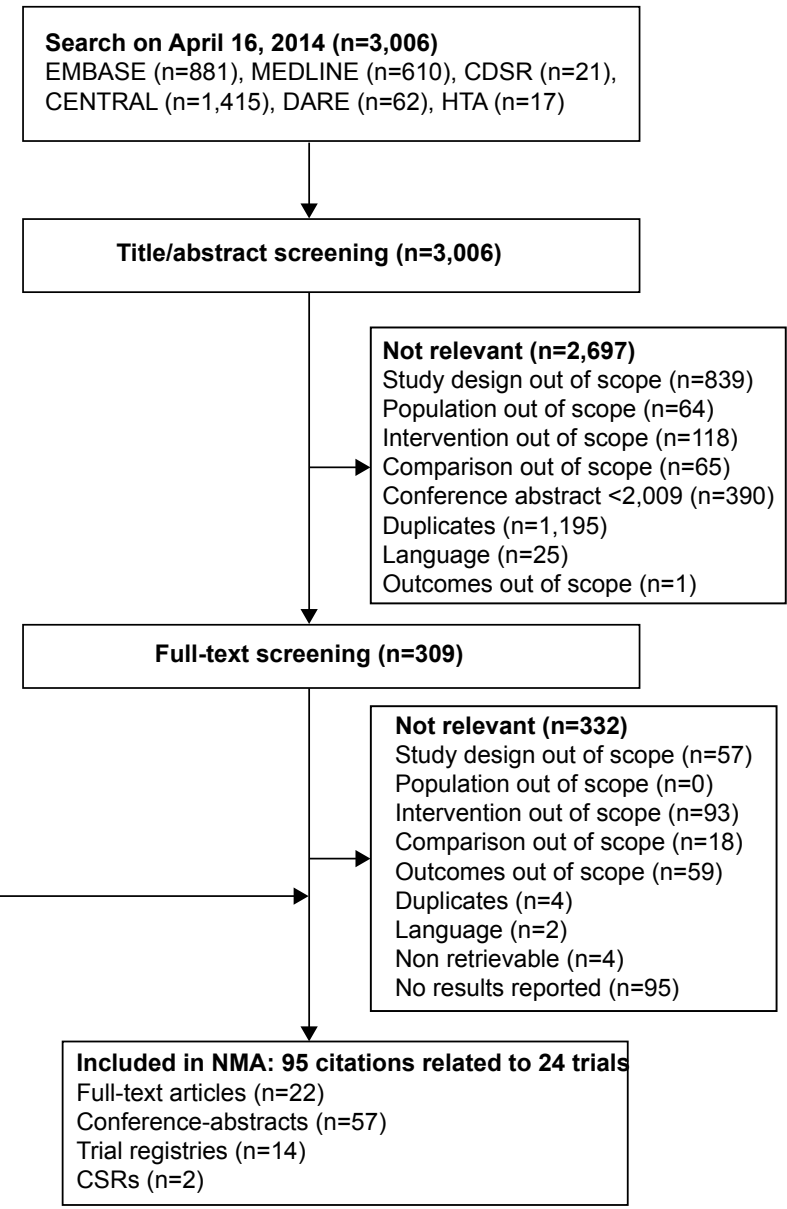

Figure I Flow chart of study selection process.

Abbreviations: CDSR, Cochrane Database of Systematic Review; CENTRAL, Cochrane Central Register of Controlled Trials; CSR, clinical study report; DARE, Database of Abstracts of Reviews of Effects; EU-CTR, EU Clinical Trials Register; HTA, Health Technology Assessment; NMA, network meta-analysis; PROSPERO, International Prospective Register of Systematic Reviews; SLR, systematic literature review; WHO ICTRP, World Health Organization International Clinical Trials Registry Platform. 


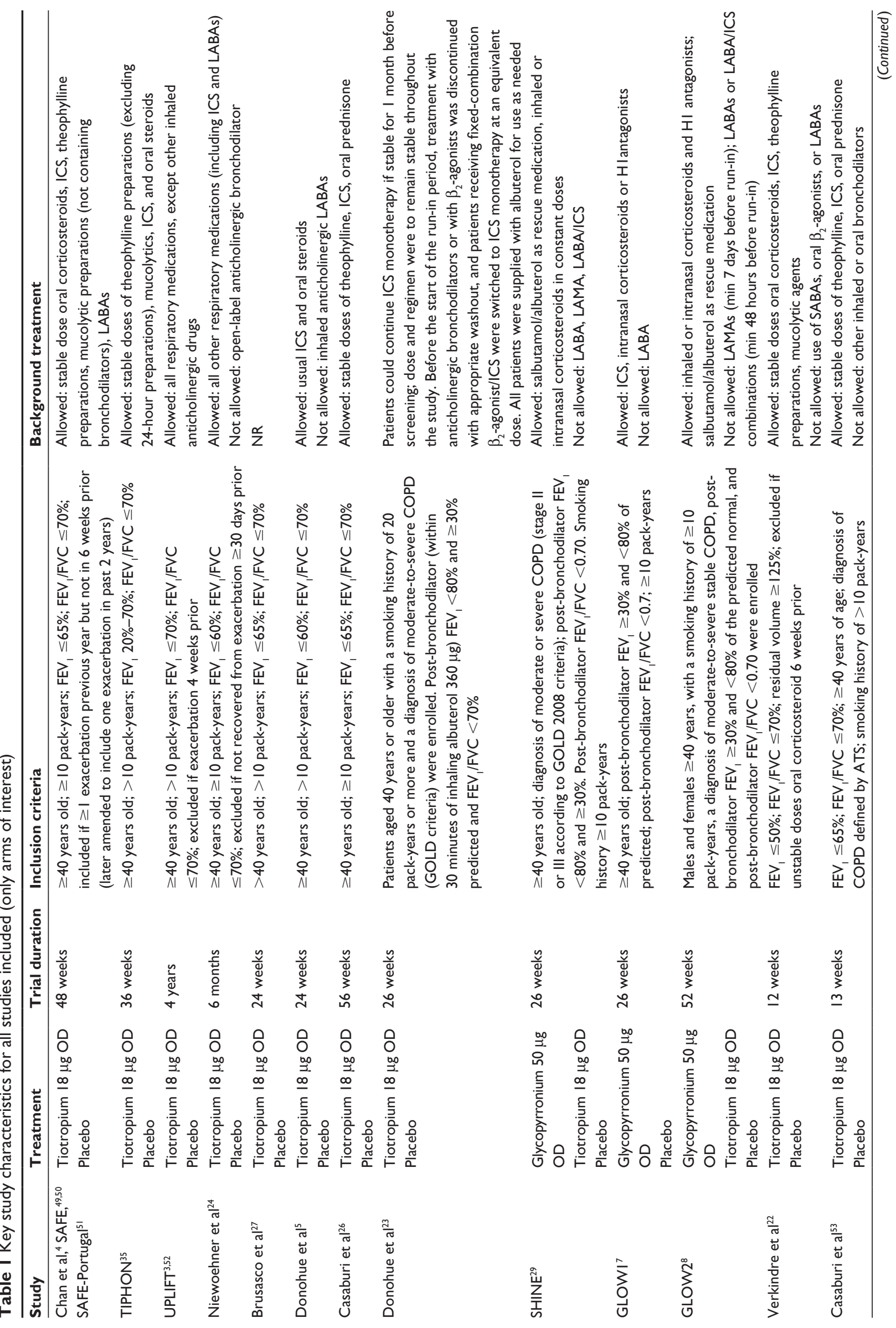




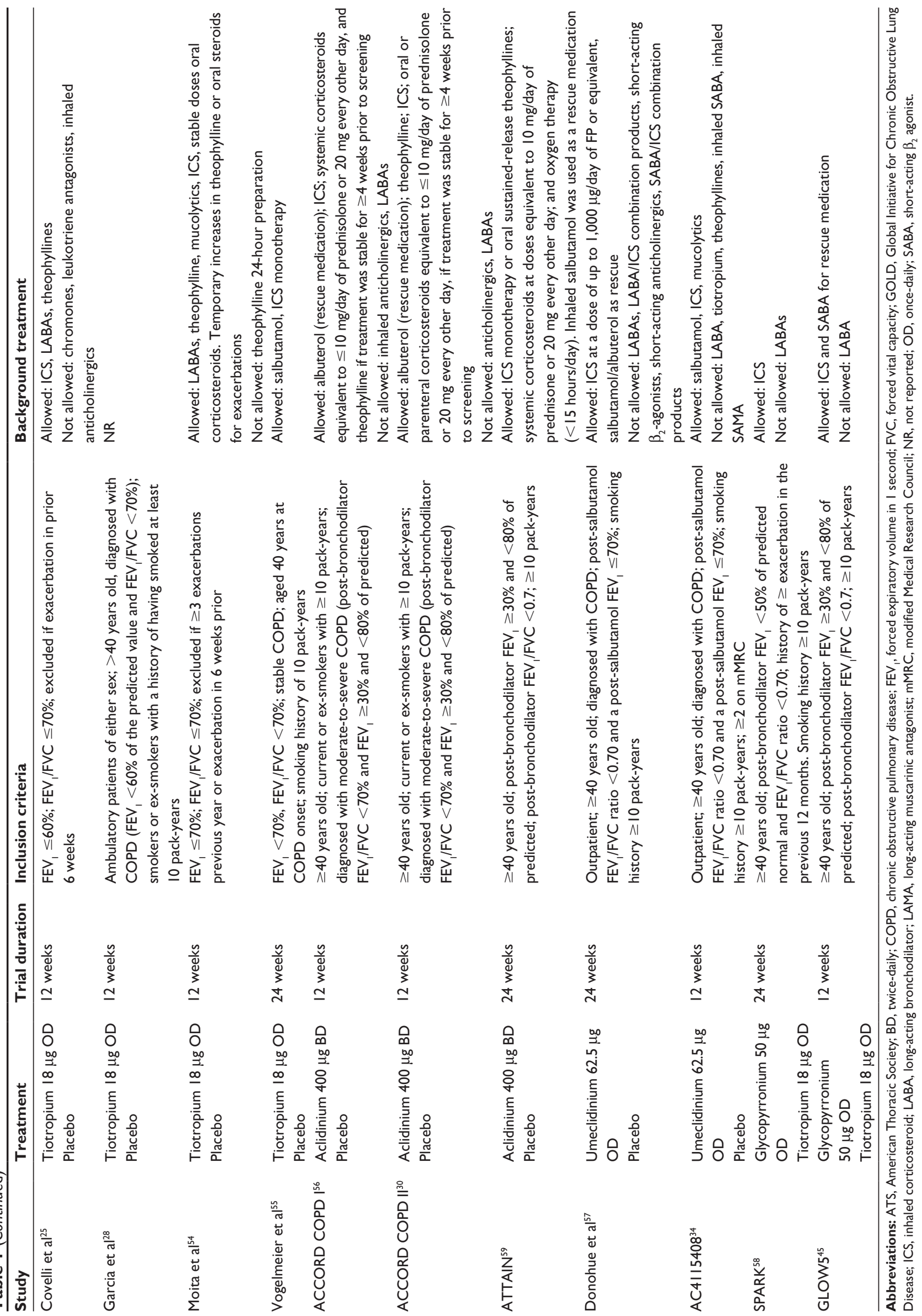




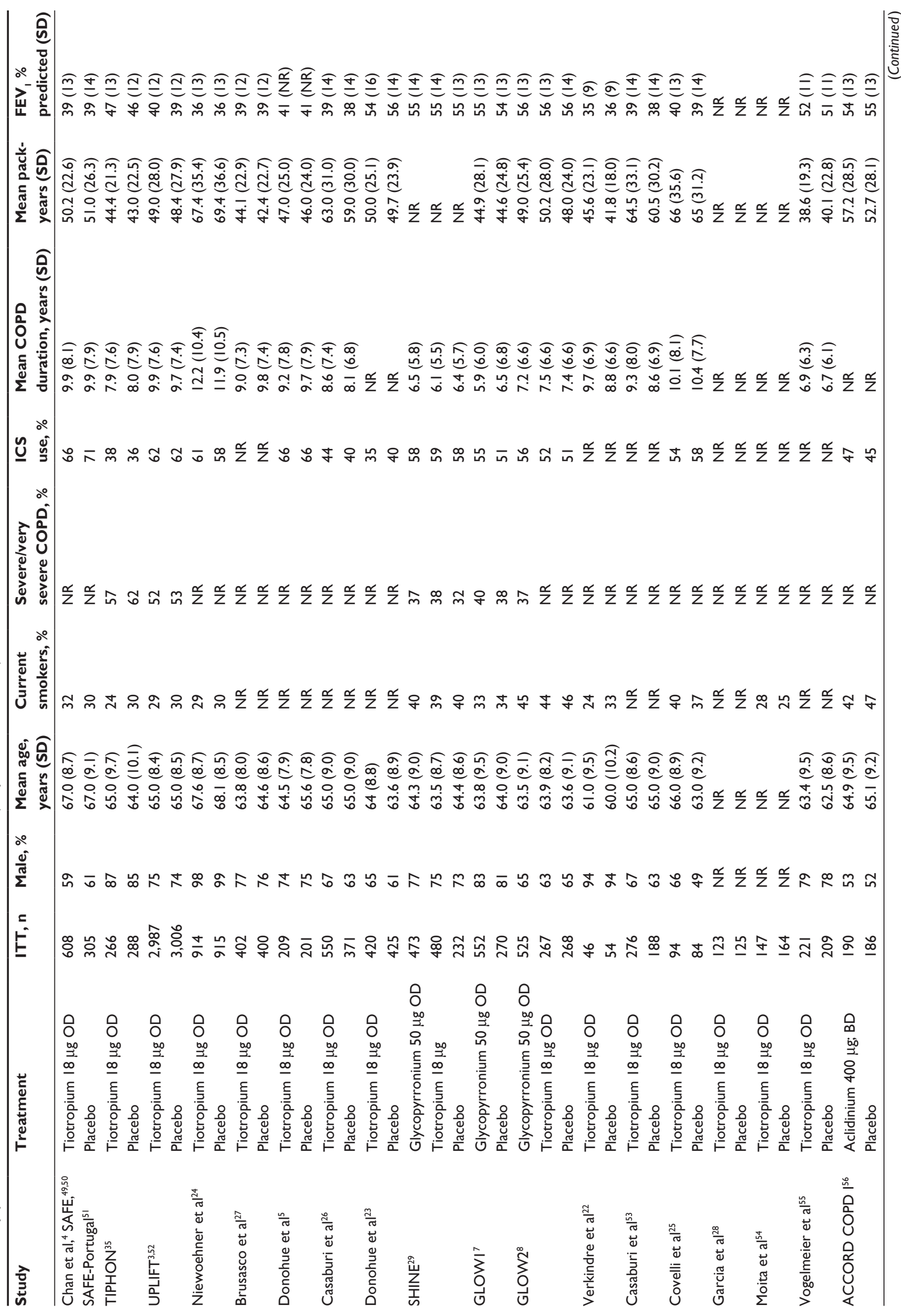




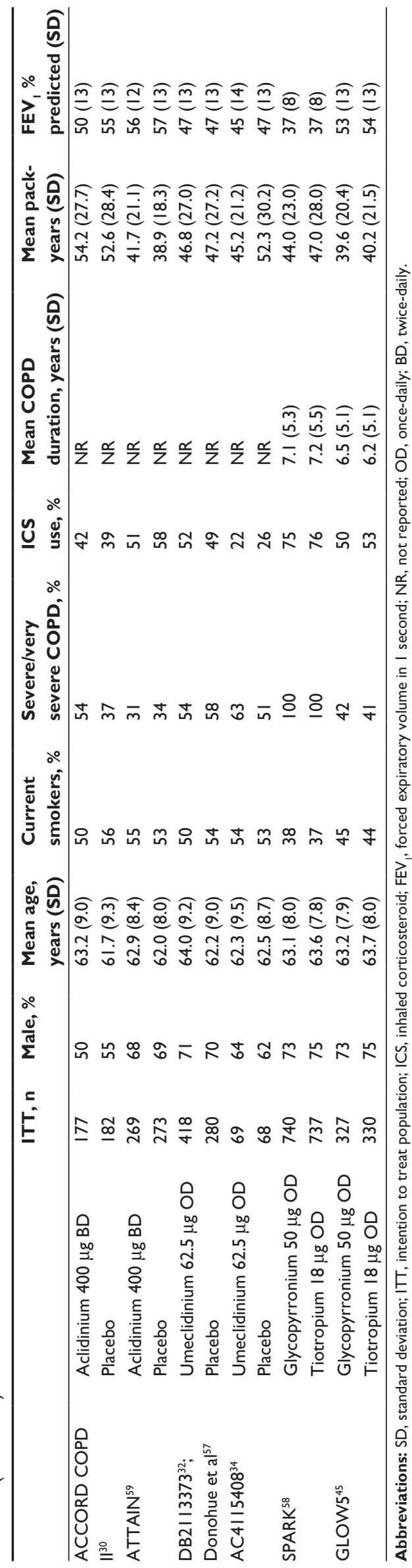

consistent at baseline, with most studies requiring a $\mathrm{FEV}_{1} /$ forced vital capacity of $\leq 0.70$. The mean $\mathrm{FEV}_{1} \%$ predicted ranged between $50 \%$ and $56 \%$ for aclidinium-treated patients, $37 \%-56 \%$ for glycopyrronium, $35 \%-55 \%$ for tiotropium, and $45 \%-48 \%$ for umeclidinium. The proportion of patients with severe or very severe COPD was reported in seven studies, ${ }^{3,29-35}$ and ranged from $31 \%$ to $100 \%$ (per treatment arm). Across all studies, the proportion of patients per arm who used inhaled corticosteroids at baseline ranged from $22 \%$ to $76 \%$. All studies included patients who were current or ex-smokers and most specified a smoking history of at least 10 years; the mean number of pack-years ranged from 38.6 to 69.4 years.

\section{Network meta-analysis}

Although there was some degree of variation in patient characteristics across studies, in general the studies were of good quality and homogeneous, and thus a valid NMA was feasible. ${ }^{36}$ The network diagram for the randomized clinical trials included in the NMA is shown in Figure 2. Studies were identified that compared aclidinium, glycopyrronium, tiotropium, and umeclidinium with placebo as the common comparator. The NMA results for trough $\mathrm{FEV}_{1}$ at 12 weeks (primary endpoint) and 24 weeks are presented, as well as secondary endpoints at 24 weeks. Supportive analyses of secondary endpoints at 12 weeks are presented in Tables S5 and S6.

Given the geometry of each network (containing only one closed loop; Figure 2), direct and indirect evidence for all outcomes was only available for the comparative efficacy of tiotropium versus placebo, glycopyrronium versus placebo, and tiotropium versus glycopyrronium. No important deviation between direct and indirect evidence was observed when the network consistency was assessed, suggesting that the consistency assumption was valid.

\section{Trough FEV, at 12 weeks (primary outcome)}

In total, 17 studies (11,935 patients) were included for the $\mathrm{FEV}_{1}$ endpoint (Figure 2A and Table 3). The minimal clinically important difference for $\mathrm{FEV}_{1}$ is $100 \mathrm{~mL} \cdot{ }^{37}$ All LAMAs investigated were more efficacious than placebo, with a mean change from baseline greater than the minimal clinically important difference (Figure 3A). The mean change from baseline in trough $\mathrm{FEV}_{1}$ was highest for umeclidinium, with a difference of $136.7 \mathrm{~mL}$ (95\% Crl: 104.20-169.20) from placebo and a $>99 \%$ probability of being better than placebo. The probability of umeclidinium being a better treatment than tiotropium, aclidinium, or glycopyrronium was $90 \%, 96 \%$, or $86 \%$, respectively. 


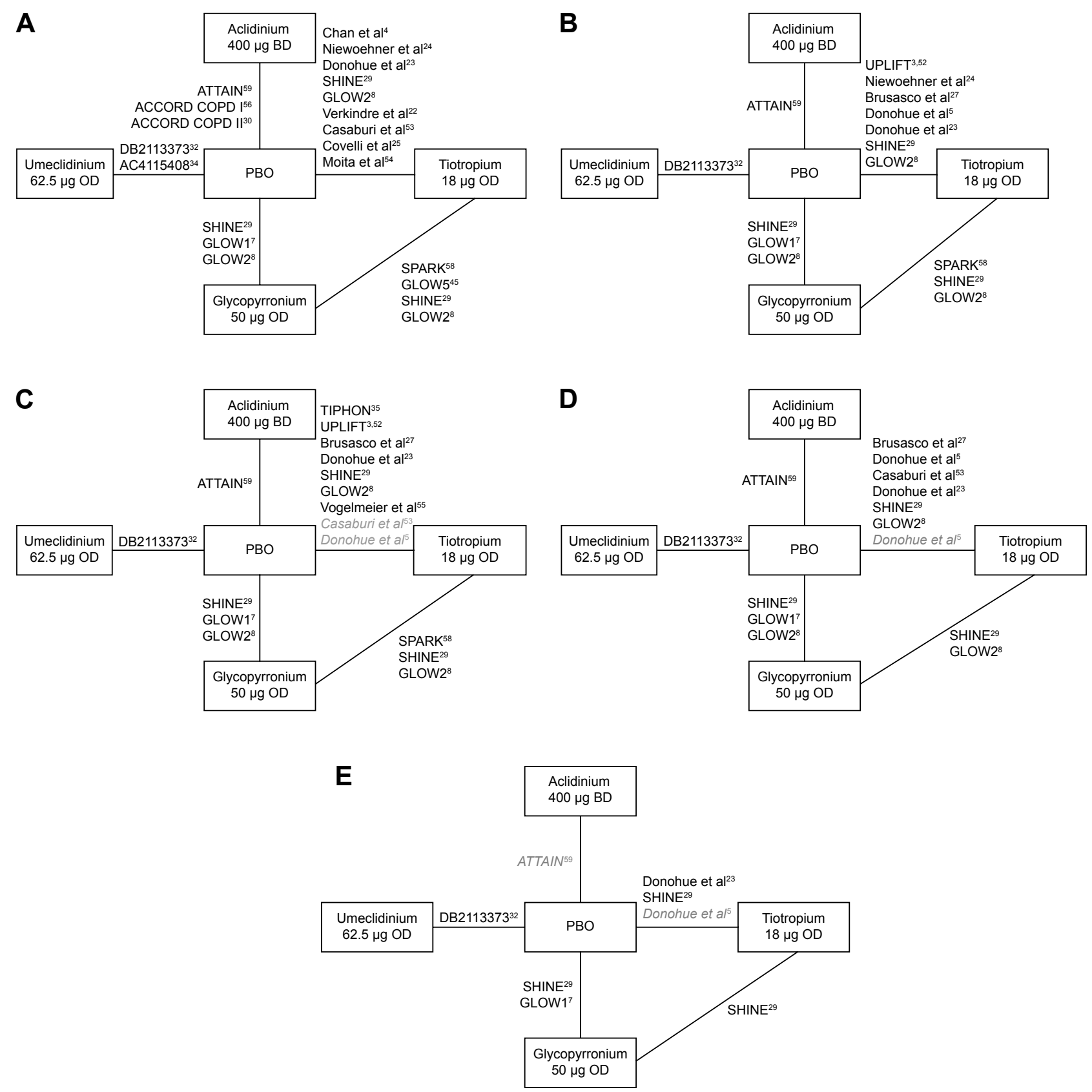

Figure 2 Overall network of studies in the network meta-analysis of umeclidinium versus other LAMAs or placebo for (A) trough FEV, at 12 weeks, (B) trough FEV, at 24 weeks, (C) SGRQ total score at 24 weeks, (D) TDI focal score at 24 weeks, and (E) rescue medication use at 24 weeks.

Note: Gray italic text indicates studies that did not report measures of uncertainty.

Abbreviations: BD, twice-daily; FEV , forced expiratory volume in I second; LAMA, long-acting muscarinic antagonist; OD, once-daily; PBO, placebo; SGRQ, St George's Respiratory Questionnaire; TDI, transitional dyspnea index.

\section{Trough FEV, at 24 weeks}

In total, eleven studies (15,663 patients) were included for the $\mathrm{FEV}_{1}$ endpoint at 24 weeks (Figure 2B and Table 3). Again, the mean change from baseline was greater than the minimal clinically important difference for all active agents. The highest change from baseline in trough $\mathrm{FEV}_{1}$ was found with glycopyrronium, with a difference of $135.8 \mathrm{~mL}$ (95\% Crl: 123.10-148.30). Glycopyrronium had a $>99 \%$ chance of being better than tiotropium, which had the next highest difference in change from baseline trough $\mathrm{FEV}_{1}$. The newest agent, umeclidinium, had a mean difference in change from baseline of $115.0 \mathrm{~mL}$ compared with placebo (95\% CrI: 74.51-155.30), with $>99 \%$ probability of being better than placebo (Figure 3B). Umeclidinium was comparable to other LAMAs for this endpoint, with only a $66 \%, 33 \%$, and $17 \%$ probability of being better than tiotropium, aclidinium, and glycopyrronium, respectively. 


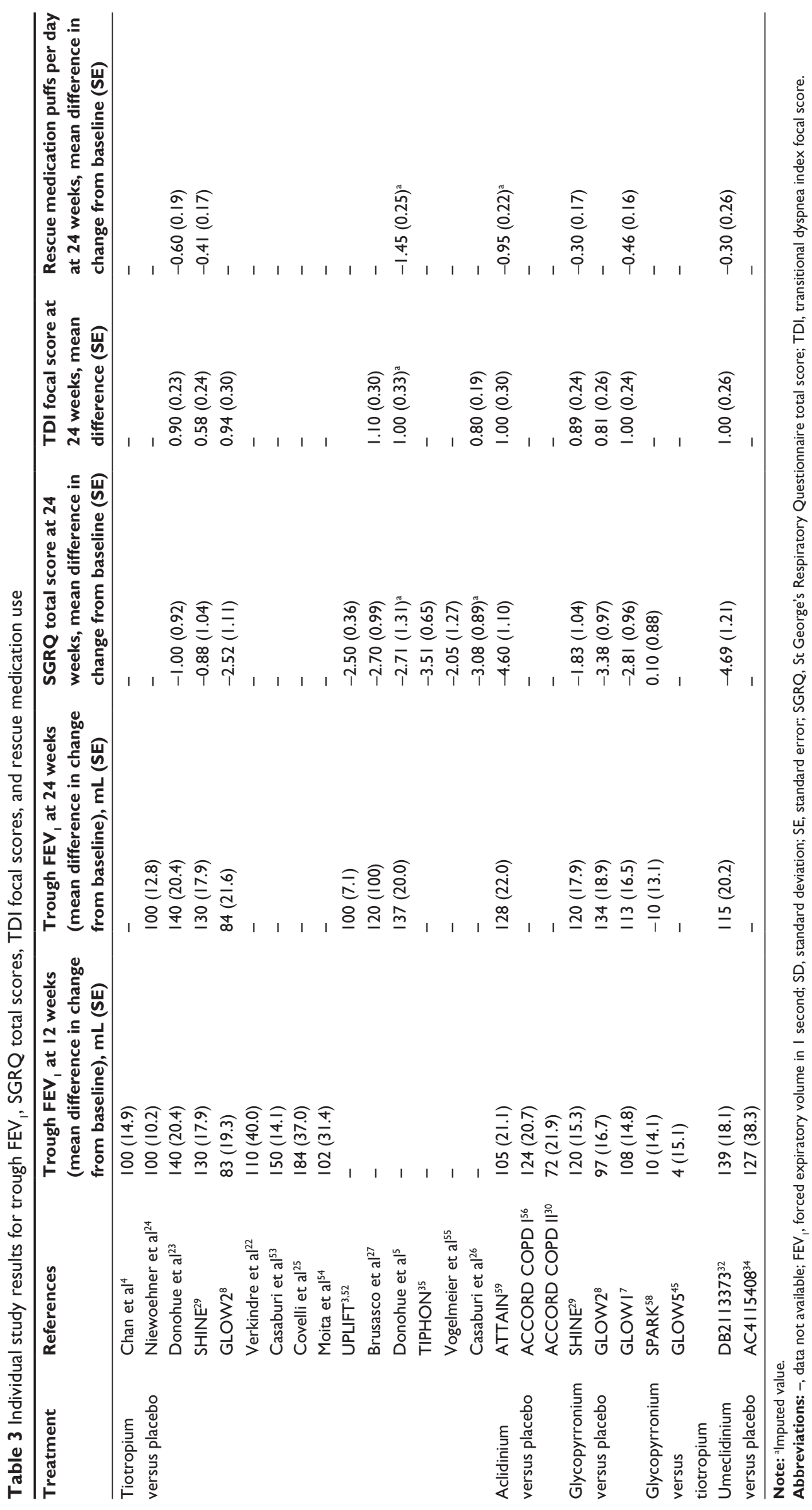


A

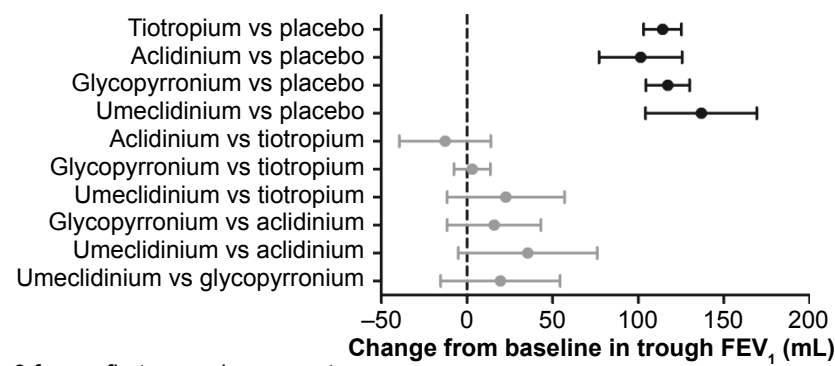

$>0$ favors first named comparator at 12 weeks (difference vs comparator)

B

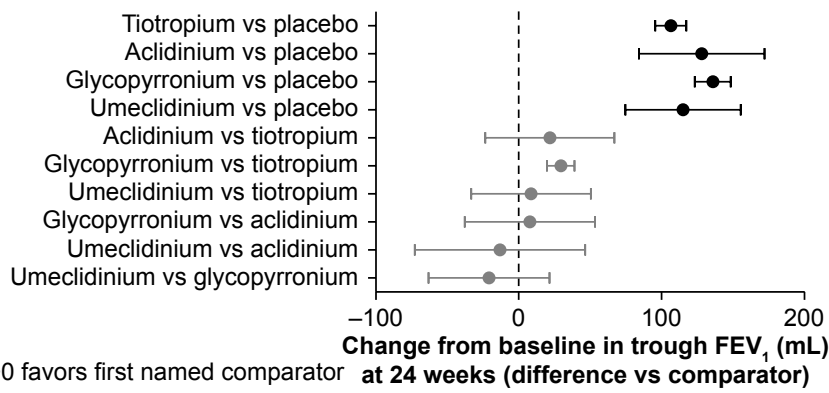

C

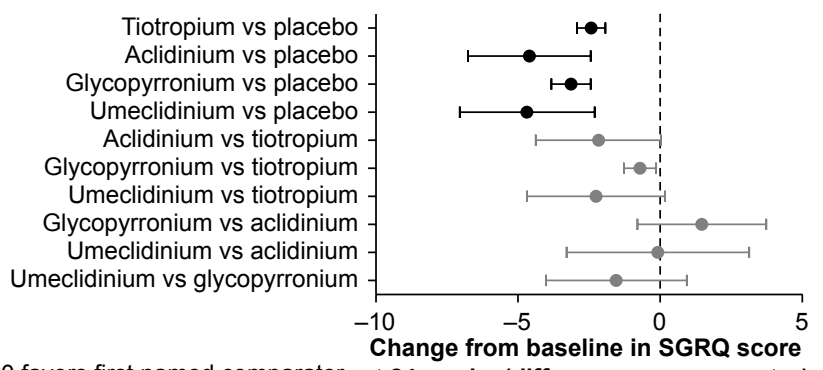

$<0$ favors first named comparator at 24 weeks (difference vs comparator)

D

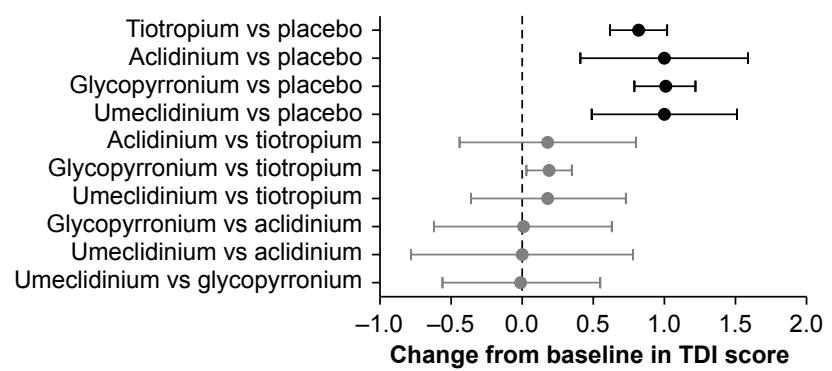

$>0$ favors first named comparator at 24 weeks (difference vs comparator)

E

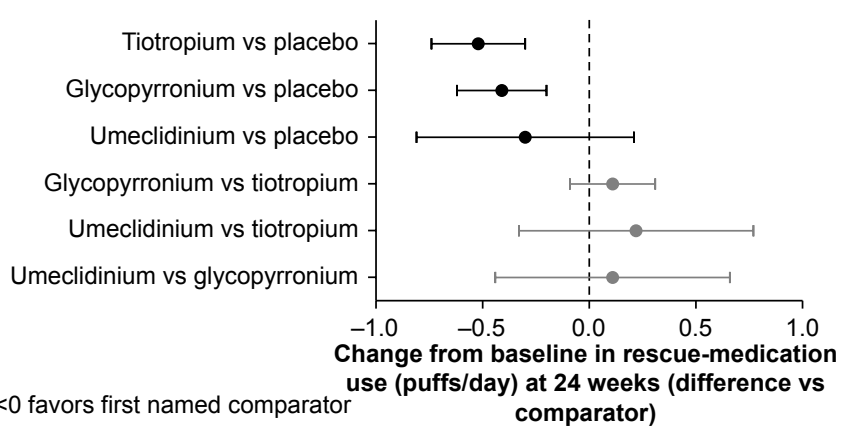

Estimate (95\% Crl)

$\boldsymbol{P}$ (better)

$114.10(103.10,125.20) \quad>99 \%$

$101.40(77.06,125.60) \quad>99 \%$

$117.20(104.50,129.90)>99 \%$

$136.70(104.20,169.20)>99 \%$

$-12.80(-39.39,13.93) \quad 17 \%$

$3.08(-7.58,13.69) \quad 72 \%$

$22.58(-11.58,56.97) \quad 90 \%$

$15.90(-11.60,43.15) \quad 87 \%$

$35.40(-5.06,76.07) \quad 96 \%$

$19.50(-15.30,54.38) \quad 86 \%$

\section{Estimate (95\% Crl)}

$106.40(95.45,117.30)$

$128.10(84.10,172.00) \quad>99 \%$

$135.80(123.10,148.30) \quad>99 \%$

$115.00(74.51,155.30) \quad>99 \%$

$21.74(-23.43,66.88) \quad 83 \%$

$29.46(19.75,38.96) \quad>99 \%$

$8.59(-33.33,50.45) \quad 66 \%$

$7.69(-37.90,53.35) \quad 63 \%$

$-13.12(-72.77,46.56) \quad 33 \%$

$-20.80(-63.14,21.54) \quad 17 \%$

Estimate (95\% Crl)

$-2.43(-2.92,-1.93)$

$-4.60(-6.76,-2.45)$

$-3.14(-3.83,-2.45)$

$-4.69(-7.05,-2.31)$

$-2.17(-4.38,0.03)$

$-0.71(-1.28,-0.15)$

$-2.26(-4.68,0.17)$

$1.46(-0.80,3.73)$

$-0.09(-3.29,3.13)$

$-1.55(-4.02,0.93)$

$P$ (better)

$>99 \%$

$>99 \%$

$>99 \%$

$>99 \%$

$97 \%$

$>99 \%$

$97 \%$

$10 \%$

$52 \%$

$89 \%$

$\begin{array}{ll}\text { Estimate } \mathbf{( 9 5 \%} \text { Crl) } & \boldsymbol{P} \text { (better) } \\ 0.82(0.62,1.02) & >99 \% \\ 1.00(0.41,1.59) & >99 \% \\ 1.01(0.79,1.22) & >99 \% \\ 1.00(0.49,1.51) & >99 \% \\ 0.18(-0.44,0.80) & 72 \% \\ 0.19(0.03,0.35) & >99 \% \\ 0.18(-0.36,0.73) & 74 \% \\ 0.01(-0.62,0.63) & 51 \% \\ 0.00(-0.78,0.78) & 50 \% \\ -0.01(-0.56,0.55) & 49 \%\end{array}$

Estimate $(95 \% \mathrm{Crl})$

$-0.52(-0.74,-0.30)$

$P$ (better)

$>99 \%$

$-0.41(-0.62,-0.20)$

$>99 \%$

$-0.30(-0.81,0.21)$

$88 \%$

$0.11(-0.09,0.31)$

$14 \%$

$0.22(-0.33,0.77)$

$22 \%$

$0.11(-0.44,0.66)$

$35 \%$

(better)

-

$99 \%$

$1 \%$

$9 \%$

)




\section{SGRQ total score at 24 weeks}

Thirteen studies (15,739 patients) were included in the examination of this endpoint (Figure $2 \mathrm{C}$ and Table 3 ). Two studies reported only the mean difference in change from baseline without any measure of uncertainty, such as $\mathrm{SE}, \mathrm{SD}$, or $95 \%$ CI. ${ }^{5,26}$ An imputed value was calculated based on the average SD of the difference in change from baseline of trials in the network. Imputing this value and adding the studies to the analysis did not impact the results.

The minimal clinically important difference for SGRQ score is 4 units. ${ }^{38}$ Relative to placebo, only umeclidinium and aclidinium mean scores were reduced by more than 4 units, although all agents had $99 \%$ probability of being better than placebo (Figure 3C). The highest difference was seen with umeclidinium, which had a $97 \%, 52 \%$, and $89 \%$ chance of being better than tiotropium, aclidinium, or glycopyrronium, respectively.

\section{TDI focal score at 24 weeks}

Nine studies (7,285 patients) were included (Figure 2D and Table 3). One study ${ }^{5}$ did not report any measure of uncertainty or an exact $P$-value; this was imputed and did not impact the results.

The minimal clinically important difference for TDI score is 1 unit. ${ }^{39}$ Aclidinium, glycopyrronium, and umeclidinium had a mean difference in change from baseline in TDI score of $\geq 1.00$ (Figure 3D). Only the mean change in TDI score for tiotropium did not reach the minimal clinically important difference.

\section{Rescue medication use at 24 weeks}

A total of six studies (4,502 patients) were included (Figure 2E and Table 3). Glycopyrronium, tiotropium, and umeclidinium reduced rescue medication use to comparable extents, with mean changes of -0.41 ( $95 \%$ CrI: -0.62 to -0.20$),-0.52$ (95 CrI: -0.74 to -0.30 ), and -0.30 puffs/day ( $95 \% \mathrm{CrI}:-0.81$ to 0.21 ), relative to placebo (Figure $3 \mathrm{E}$ ).

\section{Discussion}

In the absence of head-to-head study data and in light of new available agents, a systematic literature review and NMA was carried out to assess the relative efficacy of LAMAs for the treatment of COPD. Overall, a large number of patients $(21,311)$ were included in our analyses. Endpoints (change from baseline in trough $\mathrm{FEV}_{1}$, SGRQ total scores, TDI focal scores, and rescue medication use) were selected because they were consistently reported across all studies and deemed to be clinically important endpoints in those studies. Other endpoints, such as adverse events, exercise tolerance, and exacerbation rate, were not included, for several reasons. First, the definitions and methodology for reporting adverse events and exercise tolerance were variable across trials, precluding accurate comparisons. Second, exacerbations were studied in some longer-term trials, where a history of these events was required at entry, but were not key endpoints in most 3- and 6-month studies. Although exacerbations were beyond the scope of this NMA, another NMA performed without the inclusion of umeclidinium suggested that efficacy was comparable between aclidinium, glycopyrronium, and tiotropium for the prevention of COPD exacerbations; all reduced moderateto-severe exacerbations, compared with placebo, and all were equally effective. ${ }^{40}$

As expected, this NMA revealed that all the active LAMA treatments (aclidinium, glycopyrronium, tiotropium, and umeclidinium) were more efficacious than placebo, with each of the active therapies providing clinically relevant improvements in trough $\mathrm{FEV}_{1}(>100 \mathrm{~mL})$ at 12 and 24 weeks. Improvements in other measures (SGRQ score, TDI focal score, and rescue medication use), versus placebo, were also observed. The estimates met the minimal clinically important differences for umeclidinium (SGRQ and TDI focal score), aclidinium (SGRQ and TDI focal score), and glycopyrronium (TDI focal score only) versus placebo at 24 weeks. Overall, these findings suggest that all LAMAs are effective, compared with placebo.

Aclidinium and umeclidinium had broadly similar efficacy for lung function and patient-reported outcomes, compared with the other LAMAs examined and each other. Overall, there was no evidence that a BD regimen (ie, aclidinium) was more efficacious than OD regimens. For umeclidinium, the newest agent, there were some modest numerical improvements in 12-week lung function, compared with other LAMAs; however, the CrI crossed zero in all cases. In some cases, there were indications that glycopyrronium had superior efficacy to tiotropium, with the newer agent having a $>99 \%$ probability of being better in terms of 24-week $\mathrm{FEV}_{1}$ and SGRQ score than tiotropium. However, it should be acknowledged that the patients in the glycopyrronium trials had predominantly moderately severe COPD, compared with tiotropium trials, which tended to include patients with severe COPD.

Although there have been no direct comparisons of umeclidinium with other LAMAs in the literature (noting that head-to-head trials of umeclidinium versus glycopyrronium 
[NCT02236611], ${ }^{41}$ and umeclidinium versus tiotropium [NCT02207829], ${ }^{42}$ are currently ongoing), there have been recent direct comparisons of aclidinium versus tiotropium. In one randomized, controlled trial aclidinium had comparable bronchodilation and significantly improved symptom control, relative to tiotropium at 6 weeks, in line with our data. ${ }^{43}$ A small, randomized crossover study also suggested some improvements for $\mathrm{FEV}_{1}$ area under the curve and COPD symptoms with aclidinium versus tiotropium. ${ }^{44}$ The GLOW5 study concluded that glycopyrronium and tiotropium had similar efficacy, noting that there were non-significant improvements with glycopyrronium for TDI focal score, SGRQ total score, rescue medication use, and the rate of COPD exacerbations. ${ }^{45}$ The current analysis failed to entirely corroborate these findings, highlighting small potential efficacy differences in favor of glycopyrronium. As noted previously, this discrepancy could result from differences in baseline COPD severity between glycopyrronium and tiotropium trials.

\section{Limitations}

There are some potential limitations to this analysis. Although the endpoints selected were clinically important (and commonly reported in randomized controlled trials), they were also relatively short-term endpoints. At present, all four of the LAMAs investigated here have reported positive effects on exacerbations outcomes relative to placebo, ${ }^{7,46-48}$ but differences in study methodology, populations, and reporting methods precluded robust comparisons of LAMAs against one another in our analysis. We also focused on mean outcomes; alternative analyses examining percentage of responders, if performed on patient level data, might highlight incremental differences between the LAMAs that were not apparent when means were used. Differences in the patient populations, particularly the approximately $20 \%$ range in mean baseline $\mathrm{FEV}_{1} \%$ predicted values, and background medications may have resulted in some residual confounding influences that could not be adequately addressed with our methodology, despite attempts to select similar studies. Consequently, the findings do not carry the same weight as head-to-head randomized controlled trials; such studies are warranted to corroborate our data. Finally, the data used in the NMA were obtained from highly controlled studies with patients who have been trained in the use of different inhaler devices. Our analysis cannot account for potential handling errors or preferences for a particular device (these factors were likely to have been minimized within studies due to blinding). These inhaler-related factors highlight a need for more pragmatic COPD-effectiveness studies (less controlled) when LAMAs are compared. Such studies may allow for increased differentiation within the LAMA class driven by device choice and posology differences within the drug class. Until such head-to-head studies are available, our findings provide reassurance that umeclidinium has an efficacy profile at least on a par with the standard-of-care LAMA, tiotropium, and a profile at least as effective as other new alternative LAMAs.

\section{Conclusion}

The current data on LAMAs suggest that aclidinium, glycopyrronium, tiotropium, and umeclidinium are efficacious, relative to placebo, and the efficacy profile of newer LAMAs appears at least on a par with the standard-of-care LAMA, tiotropium. Until randomized controlled head-to-head trials can be carried out, there is little robust evidence to suggest that one is more efficacious than the others, and the choice of LAMA should depend on physician's and patient's preference.

\section{Acknowledgments}

The analysis was sponsored by GSK (GSK study number: 201280). Editorial support in the form of development of the draft outline in consultation with the authors, editorial suggestions to draft versions of this paper, assembling tables and figures, collating author comments, copyediting, fact checking, referencing, and graphic services was provided by Emma McConnell, PhD, at Gardiner-Caldwell Communications (Macclesfield, UK) and was funded by GSK.

\section{Author contributions}

ASI, ELH, YSP, and AK contributed to the study design and were involved in the analysis or interpretation of the data. ELH was also involved in the data acquisition. All authors drafted the manuscript.

\section{Disclosure}

ASI and YSP are employees of GSK and hold stocks in GSK. ELH and AK are employees of Mapi and received payment from GSK for consultancy during the conduct of this study. The authors report no other conflicts of interest in this work.

\section{References}

1. Global Initiative for Chronic Obstructive Lung Disease (GOLD) [database on the internet]. Global strategy for the diagnosis, management, and prevention of chronic obstructive pulmonary disease. 2015. Available from: http:/www.goldcopd.org/uploads/users/files/ GOLD_Report_2015_Apr2.pdf. Accessed May 11, 2015.

2. Kew KM, Dias S, Cates CJ. Long-acting inhaled therapy (beta-agonists, anticholinergics and steroids) for COPD: a network meta-analysis. Cochrane Database Syst Rev. 2014;26:3. 
3. Tashkin DP, Celli B, Senn S, et al. A 4-year trial of tiotropium in chronic obstructive pulmonary disease. N Engl J Med. 2008;359:1543-1554.

4. Chan CKN, Maltais F, Sigouin C, Haddon JM, Ford GT. A randomized controlled trial to assess the efficacy of tiotropium in Canadian patients with chronic obstructive pulmonary disease. Can Respir J. 2007;14: 465-472.

5. Donohue JF, van Noord JA, Bateman ED, et al. A 6-month, placebocontrolled study comparing lung function and health status changes in COPD patients treated with tiotropium or salmeterol. Chest. 2002; 122:47-55.

6. Jones PW, Agusti A, Chanez P, et al. A phase III study evaluating aclidinium bromide, a novel long-acting antimuscarinic, in patients with COPD: ACCLAIM/COPD I. Am J Res Crit Care Med. 2009; 179:A6180.

7. D'Urzo A, Ferguson GT, van Noord JA, et al. Efficacy and safety of once-daily NVA237 in patients with moderate-to-severe COPD: the GLOW1 trial. Respir Res. 2011;12:156.

8. Kerwin E, Hebert J, Gallagher N, et al. Efficacy and safety of NVA237 versus placebo and tiotropium in patients with COPD: the GLOW2 study. Eur Respir J. 2012;40:1106-1114.

9. Trivedi R, Richard N, Mehta R, Church A. Umeclidinium in patients with COPD: a randomised, placebo-controlled study. Eur Respir J. 2014; 43:72-81.

10. Cope S, Donohue JF, Jansen JP, et al. Comparative efficacy of longacting bronchodilators for COPD - a network meta-analysis. Respir Res. 2013;14.

11. Karabis A, Lindner L, Mocarski M, Huisman E, Greening A. Comparative efficacy of aclidinium versus glycopyrronium and tiotropium, as maintenance treatment of moderate to severe COPD patients: a systematic review and network meta-analysis. Int J COPD. 2013;8: $405-423$.

12. GSK Study 201280 [database on the internet]. Available from: http://www. gsk-clinicalstudyregister.com/study/201280\#ps. Accessed March 31, 2015.

13. PRISMA Guidelines [database on the internet]. Available from: http:// www.prisma-statement.org/. Accessed April 1, 2015.

14. Allgemeine Methoden [database on the internet]. Available from: https://www.iqwig.de/download/IQWiG_Methoden_Version_4-2.pdf. Accessed June 25, 2015.

15. Cope S, Zhang J, Saletan S, Smiechowski B, Jansen JP, Schmid P. A process for assessing the feasibility of a network meta-analysis: a case study of everolimus in combination with hormonal therapy versus chemotherapy for advanced breast cancer. BMC Med. 2014; 12:93.

16. Salanti G. Indirect and mixed-treatment comparison, network, or multiple-treatments meta-analysis: many names, many benefits, many concerns for the next generation evidence synthesis tool. Res Synth Methods. 2012;3:80.

17. Hoaglin DC, Hawkins N, Jansen JP, et al. Conducting indirecttreatment-comparison and network-meta-analysis studies: report of the ISPOR Task Force on Indirect Treatment Comparisons Good Research Practices: Part 2. Value Health. 2011;14:429-437.

18. Dias S, Welton NJ, Sutton AJ, Ades AE. NICE DSU Technical Support Document 2: a generalised linear modelling framework for pairwise and network meta-analysis of randomised controlled trials [database on the internet]. Available from: http://www.nicedsu.org.uk/TSD2\%20 General\%20meta\%20analysis\%20corrected\%2015April2014.pdf. Accessed May 11, 2015.

19. Dias S, Welton NJ, Caldwell DM, Ades AE. Checking consistency in mixed treatment comparison meta-analysis. Stat Med. 2010; 29:932-944.

20. Spiegelhalter DJ, Best NG, Carlin BR, van der Linde A. Bayesian measures of model complexity and fit. J R Stat Soc Series B Stat Methodol. 2002;64:583-616.

21. Lunn DJ, Thomas A, Best N, Spiegelhalter D. WinBUGS - a Bayesian modelling framework: concepts, structure, and extensibility. Stat Comput. 2000;10:325-337.
22. Verkindre C, Bart F, Aguilaniu B, et al. The effect of tiotropium on hyperinflation and exercise capacity in chronic obstructive pulmonary disease. Respiration. 2006;73:420-427.

23. Donohue JF, Fogarty C, Lotvall J, et al. Once-daily bronchodilators for chronic obstructive pulmonary disease indacaterol versus tiotropium. Am J Respir Crit Care Med. 2010;182:155-162.

24. Niewoehner DE, Rice K, Cote C, et al. Prevention of exacerbations of chronic obstructive pulmonary disease with tiotropium, a once-daily inhaled anticholinergic bronchodilator: a randomized trial. Ann Intern Med. 2005;143:317-326.

25. Covelli H, Bhattacharya S, Cassino C, Conoscenti C, Kesten S. Absence of electrocardiographic findings and improved function with once-daily tiotropium in patients with chronic obstructive pulmonary disease. Pharmacotherapy. 2005;25:1708-1718.

26. Casaburi R, Mahler DA, Jones PW, et al. A long-term evaluation of once-daily inhaled tiotropium in chronic obstructive pulmonary disease. Eur Respir J. 2002;19:217-224

27. Brusasco V, Hodder R, Miravitlles M, Korducki L, Towse L, Kesten S. Health outcomes following treatment for six months with once daily tiotropium compared with twice daily salmeterol in patients with COPD. Thorax. 2003;58:399-404.

28. Garcia RF. A randomised, double-blind, placebo-controlled, 12 weeks trial to evaluate the effect of Tiotropium Inhalation Capsules on the magnitude of exercise, measured using an accelerometer, in patients with Chronic Obstructive Pulmonary Disease (COPD). Boehringer Ingelheim Trial Results. NLM Identifier: NCT00144326. 2007. Available from: http://trials.boehringer-ingelheim.com/content/dam/internet/ opu/clinicaltrial/com_EN/results/205/205.269.pdf. Accessed October 19, 2015.

29. Bateman ED, Ferguson GT, Barnes N, et al. Dual bronchodilation with QVA149 versus single bronchodilator therapy: the SHINE study. Eur Respir J. 2013;42:1484-1494.

30. Rennard SI, Scanlon PD, Ferguson GT, et al. ACCORD COPD II: a randomized clinical trial to evaluate the 12 -week efficacy and safety of twice-daily aclidinium bromide in chronic obstructive pulmonary disease patients. Clin Drug Invest. 2013;33:893-904.

31. GlaxoSmithKline. A multicenter trial comparing the efficacy and safety of GSK573719/GW642444 with GSK573719 and with tiotropium over 24 weeks in subjects with COPD. Clinical Study Report - DB2113374. NLM identifier: NCT01316913. 2013. Available from: https://gsk.sylogent.com/files/sam-2588-gsk-113374-clinical-study-report-redact-v02. pdf. Accessed October 19, 2015.

32. GlaxoSmithKline. A 24-week, randomized, double-blind, placebocontrolled study to evaluate the efficacy and safety of GSK573719/ GW642444 inhalation powder and the individual components delivered once-daily via a novel dry powder inhaler in subjects with chronic obstructive pulmonary disease. Clinical Study Report - DB2113373. NLM identifier: NCT01313650. 2013. Available from: https://gsk. sylogent.com/files/sam-3623-gsk-113373-clinical-study-report-redactv03.pdf. Accessed October 19, 2015.

33. GlaxoSmithKline. 24-week trial comparing GSK573719/GW642444 with GW642444 and with tiotropium in chronic obstructive pulmonary disease. Clinical Study Report - DB2113360. NLM identifier: NCT01316900. 2013. Available from: https://gsk.sylogent.com/files/ sam-2504-gsk-113360-clinical-study-report-redact-v02.pdf. Accessed October 19, 2015.

34. GlaxoSmithKline. A 12-week, randomized, double-blind, placebocontrolled, parallel-group study to evaluate the efficacy and safety of GSK573719 delivered once-daily via a novel dry powder inhaler in subjects with chronic obstructive pulmonary disease. Clinical Study Report-AC4115408. NLM identifier: NCT01387230. 2013. Available from: https://gsk.sylogent.com/files/sam-2802-gsk-115408-clinicalstudy-report-redact.pdf. Accessed October 19, 2015.

35. Tonnel AB, Perez T, Grosbois JM, Verkindre C, Bravo ML, Brun M. Effect of tiotropium on health-related quality of life as a primary efficacy endpoint in COPD. Int J Chron Obstruct Pulmon Dis. 2008;3: 301-310. 
36. Jansen JP, Trikalinos T, Cappelleri JC, et al. Indirect treatment comparison/network meta-analysis study questionnaire to assess relevance and credibility to inform health care decision making: an ISPOR-AMCP-NPC Good Practice Task Force Report. Value Health. 2014; $17: 157-173$

37. Donohue JF. Minimal clinically important differences in COPD lung function. COPD. 2005;2:111-124.

38. Jones PW. St George's respiratory questionnaire: MCID. COPD. 2005;2:75-79.

39. Mahler DA, Witek TJ. The MCID of the transition dyspnea index is a total score of one unit. COPD. 2005;2:99-103.

40. Oba Y, Lone NA. Comparative efficacy of long-acting muscarinic antagonists in preventing COPD exacerbations: a network meta-analysis and meta-regression. Ther Adv Respir Dis. 2015;9:3-15.

41. GlaxoSmithKline. A randomized, parallel-group, open-label study to evaluate the efficacy and safety of umeclidinium (UMEC) 62.5 mcg compared with glycopyrronium $44 \mathrm{mcg}$ in subjects with chronic obstructive pulmonary disease (COPD). Available from: http://www. gsk-clinicalstudyregister.com/study/201315\#ps. Accessed June 25, 2015.

42. GlaxoSmithKline. A randomized, blinded, double-dummy, parallelgroup study to evaluate the efficacy and safety of umeclidinium (UMEC) $62.5 \mathrm{mcg}$ compared with tiotropium $18 \mathrm{mcg}$ in subjects with chronic obstructive pulmonary disease (COPD). Available from: http://www. gsk-clinicalstudyregister.com/study/201316\#ps. Accessed June 25, 2015.

43. Beier J, Kirsten AM, Mroz R, et al. Efficacy and safety of aclidinium bromide compared with placebo and tiotropium in patients with moderate-to-severe chronic obstructive pulmonary disease: results from a 6-week, randomized, controlled phase IIIb Study. COPD. 2013; 10:511-522.

44. Fuhr R, Magnussen H, Sarem K, et al. Efficacy of aclidinium bromide $400 \mu \mathrm{g}$ twice daily compared with placebo and tiotropium in patients with moderate to severe COPD. Chest. 2012;141:745-752.

45. Chapman KR, Beeh KM, Beier J, et al. A blinded evaluation of the efficacy and safety of glycopyrronium, a once-daily long-acting muscarinic antagonist, versus tiotropium, in patients with COPD: the GLOW5 study. BMC Pulm Med. 2014;14:4.

46. Tashkin D, Celli B, Kesten S, Lystig T, Decramer M. Effect of tiotropium in men and women with COPD: results of the 4-year UPLIFT (R) trial. Respir Med. 2010;104:1495-1504.

47. Jones PW, Rennard SI, Agusti A, et al. Efficacy and safety of oncedaily aclidinium in chronic obstructive pulmonary disease. Respir Res. 2011;12:55.

48. Donohue JF, Niewoehner D, Brooks J, O’Dell D, Church A. Safety and tolerability of once-daily umeclidinium/vilanterol 125/25 mcg and umeclidinium $125 \mathrm{mcg}$ in patients with chronic obstructive pulmonary disease: results from a 52-week, randomized, double-blind, placebocontrolled study. Respir Res. 2014;15:78.
49. Spiriva Assessment of FEV1 (SAFE). The effect of inhaled tiotropium bromide (18 mcg once daily) on the change in FEV1 during long-term treatment in patients with COPD. A one-year parallel group, doubleblind, randomised, placebo-controlled study. Boehringer Ingelheim Clinical Trial Register. NLM: NCT00277264. 2005. Available from: http://trials.boehringer-ingelheim.com/content/dam/internet/opu/clinicaltrial/com_EN/results/205/205.259_U05-3345.pdf. Accessed October $19,2015$.

50. Spiriva ${ }^{\circledR}$ Assessment of FEV1 (SAFE). Boehringer Ingelheim. 2013. NLM identifier: NCT00277264. Available from: http://trials.boehringer-ingelheim.com/content/dam/internet/opu/clinicaltrial/com_EN/ results/205/205.259_U05-3345.pdf Accessed October 19, 2015.

51. Spiriva (Tiotropium Bromide) Assessment of FEV1 - (SAFE-Portugal). Boehringer Ingelheim. 2013. NLM identifier: NCT00239408. Available from: http://rials.boehringer-ingelheim.com/content/dam/internet/opu/ clinicaltrial/com_EN/results/205/205.282_U06-2124.pdf. Accessed: October 19, 2015.

52. Evaluation of the long-term effects of Spiriva on lung function in COPD patients. Boehringer Ingelheim. 2005. NLM identifier: NCT00144339. Available from: https:/clinicaltrials.gov/ct2/show/ results/NCT00144339. Accessed October 19, 2015.

53. Casaburi R, Briggs DD, Donohue JF, Serby CW, Menjoge SS, Witek TJ. The spirometric efficacy of once-daily dosing with tiotropium in stable COPD - a 13-week multicenter trial. Chest. 2000;118:1294-1302.

54. Moita J, Barbara C, Cardoso J, et al. Tiotropium improves FEV1 in patients with COPD irrespective of smoking status. Pulm Pharmacol Ther. 2008;21:146-151

55. Vogelmeier C, Kardos P, Harari S, Gans SJM, Stenglein S, Thirlwell J. Formoterol mono- and combination therapy with tiotropium in patients with COPD: a 6-month study. Respir Med. 2008;102:1511-1520.

56. Kerwin EM, D'Urzo AD, Gelb AF, Lakkis H, Garcia GE, Caracta CF. Efficacy and safety of a 12-week treatment with twice-daily aclidinium bromide in COPD patients (ACCORD COPD I). COPD. 2012;9:90-101.

57. Donohue JF, Maleki-Yazdi MR, Kilbride S, Mehta R, Kalberg C, Church A. Efficacy and safety of once-daily umeclidinium/vilanterol $62.5 / 25 \mathrm{mcg}$ in COPD. Respir Med. 2013;107:1538-1546.

58. Wedzicha JA, Decramer M, Ficker JH, et al. Analysis of chronic obstructive pulmonary disease exacerbations with the dual bronchodilator QVA149 compared with glycopyrronium and tiotropium (SPARK): a randomised, double-blind, parallel-group study. Lancet Respir Med. 2013;1:199-209.

59. Jones PW, Singh D, Bateman ED, et al. Efficacy and safety of twicedaily aclidinium bromide in COPD patients: the ATTAIN study. Eur Respir J. 2012;40:830-836. 


\section{Supplementary materials}

Table SI Search strategy for the systematic review

\begin{tabular}{|c|c|c|c|}
\hline & & MEDINE® In-Process and Other Non-Indexed Citations and MEDINF® & \\
\hline & & Ovid & \\
\hline & f search & April 16, 2014 & \\
\hline & mits & 1946-2014 Week 15 & \\
\hline & & $\begin{array}{l}\text { Lines 6-13 are from the search filter: BMJ Clinical Evidence Strategy (MEDLINE randomised controlled } \\
\text { using Ovid). Available from: http://clinicalevidence.bmi.com/x/set/static/ebm/learn/665076.html (accessec } \\
\text { 20I4) }\end{array}$ & $\begin{array}{l}\text { trategy } \\
\text { oril } 14 \text {, }\end{array}$ \\
\hline \# & Search & & Results, $n$ \\
\hline 1 & $\begin{array}{l}\text { (formot } \\
\text { or tiotrc } \\
\text { "237") } \\
\text { pressair } \\
\text { or vilant }\end{array}$ & $\begin{array}{l}\text { r eformoterol or foradil or oxis or atimos modulite or atock or perforomist or salmeterol or serevent } \\
\text { or spiriva or Ba } 679 \text { BR or indacaterol or onbrez or arcapta or NVA-237 or NVA237 or (NVA adj } \\
\text { opyrronium bromide or glycopyrrolate or seebri or enurev breezhaler or aclidinium bromide or tudorza } \\
\text { lira genuair or symbicort or advair or seretide or olodaterol or striverdi or umeclidinium or GSK5737I9 } \\
\text { or GW642444 or QVAI49 or relvar/breo or zephyr or anoro ellipta).ti,ab,nm. }\end{array}$ & 5,491 \\
\hline 2 & $\exp$ Puln & y Disease, Chronic Obstructive/or exp Chronic obstructive lung disease/ & 35,415 \\
\hline 3 & $\begin{array}{l}\text { (COPD } \\
\text { obstruct }\end{array}$ & $\begin{array}{l}\text { ronic obstructive pulmonary disease or COAD or chronic obstructive airway disease or chronic } \\
\text { ng disease or chronic bronchitis or emphysema).ti,ab. }\end{array}$ & 60,286 \\
\hline 4 & 2 or 3 & & 69,295 \\
\hline 5 & I and 4 & & 1,647 \\
\hline 6 & "Randon & controlled trial".pt. & 370,219 \\
\hline 7 & (random & placebo $\$$ or single blind $\$$ or double blind $\$$ or triple blind $\$$ ).ti,ab. & 782,910 \\
\hline 8 & (retracti & publication or retracted publication).pt. & 6,430 \\
\hline 9 & 6 or 7 o & & 867,607 \\
\hline 10 & (animals & umans).sh. & $3,829,658$ \\
\hline 11 & $\begin{array}{l}((\text { comme } \\
\text { "random }\end{array}$ & $\begin{array}{l}\text { editorial or meta-analysis or practice-guideline or review or letter or journal correspondence) not } \\
\text { controlled trial").pt. }\end{array}$ & $3,187,191$ \\
\hline 12 & $\begin{array}{l}\text { (random } \\
\text { controll }\end{array}$ & $\begin{array}{l}\text { I or random digit } \$ \text { or random effect } \$ \text { or random survey or random regression).ti,ab. not "randomised } \\
\text { l".pt. }\end{array}$ & 47,025 \\
\hline 13 & 9 not $(1$ & I or 12) & 649,371 \\
\hline 14 & 5 and 13 & & 637 \\
\hline 15 & Limit 14 & nglish or German) & 610 \\
\hline$a b$, & bt, sh, ti: se & s performed in abstract, name of substance, publication type, subject heading, and title fields, respectively & \\
\hline & $\begin{array}{l}\text { se } \\
\text { m search } \\
\text { mits }\end{array}$ & $\begin{array}{l}\text { EMBASE } \\
\text { Ovid } \\
\text { April } 16,2014 \\
\text { I988-2014 Week I5 } \\
\text { Lines 6-12 are from the search filter: BMJ Clinical Evidence Strategy (EMBASE randomized controlled t1 } \\
\text { Ovid). Available from: http://clinicalevidence.bmi.com/x/set/static/ebm/learn/665076.html (accessed on A }\end{array}$ & $\begin{array}{l}\text { ategy using } \\
\text { 2014) }\end{array}$ \\
\hline \# & Search & & Results, $n$ \\
\hline 1 & $\begin{array}{l}\text { (formot } \\
\text { or tiotrc } \\
\text { "237") } \\
\text { pressair } \\
\text { or vilant }\end{array}$ & $\begin{array}{l}\text { r eformoterol or foradil or oxis or atimos modulite or atock or perforomist or salmeterol or serevent } \\
\text { or spiriva or Ba } 679 \text { BR or indacaterol or onbrez or arcapta or NVA-237 or NVA237 or (NVA adj } \\
\text { opyrronium bromide or glycopyrrolate or seebri or enurev breezhaler or aclidinium bromide or tudorza } \\
\text { lira genuair or symbicort or advair or seretide or olodaterol or striverdi or umeclidinium or GSK5737I9 } \\
\text { or GW642444 or QVAI49 or relovair or zephyr or anoro ellipta).ti,ab. }\end{array}$ & 6,554 \\
\hline 2 & exp Puln & y Disease, Chronic Obstructive/or exp Chronic obstructive lung disease/ & 62,723 \\
\hline 3 & $\begin{array}{l}\text { (COPD } \\
\text { obstruct }\end{array}$ & $\begin{array}{l}\text { ronic obstructive pulmonary disease or COAD or chronic obstructive airway disease or chronic } \\
\text { ng disease or chronic bronchitis or emphysema).ti,ab. }\end{array}$ & 65,503 \\
\hline 4 & 2 or 3 & & 87,605 \\
\hline 5 & I and 4 & & 2,349 \\
\hline 6 & (random & placebo $\$$ or single blind $\$$ or double blind $\$$ or triple blind $\$$ ).ti,ab. & 893,801 \\
\hline 7 & RETRAC & ARTICLE/ & 6,430 \\
\hline 8 & 6 or 7 & & 900,087 \\
\hline 9 & (animal\$ & human\$).sh,hw. & $2,500,858$ \\
\hline 10 & (book o & erence paper or editorial or letter or review).pt. not exp randomised controlled trial/ & $3,608,293$ \\
\hline $\mathrm{II}$ & $\begin{array}{l}\text { (random } \\
\text { randomi }\end{array}$ & $\begin{array}{l}\text { \$ or random digit } \$ \text { or random effect } \$ \text { or random survey or random regression).ti,ab. not exp } \\
\text { ontrolled trial/ }\end{array}$ & 51,550 \\
\hline
\end{tabular}


Table SI (Continued)

\begin{tabular}{|c|c|c|c|}
\hline \# & \multicolumn{2}{|c|}{ Searches } & Results, $\mathbf{n}$ \\
\hline 12 & \multicolumn{2}{|c|}{8 not $(9$ or 10 or 11$)$} & 681,639 \\
\hline 13 & \multicolumn{2}{|c|}{5 and 12} & 914 \\
\hline 14 & \multicolumn{2}{|c|}{ Limit I3 to (English or German) } & 881 \\
\hline \multirow{5}{*}{\multicolumn{2}{|c|}{$\begin{array}{l}\text { Database } \\
\text { Platform } \\
\text { Date of search } \\
\text { Time limits } \\
\text { Filters }\end{array}$}} & \multicolumn{2}{|l|}{ CENTRAL and CDSR } \\
\hline & & Cochrane & \\
\hline & & April 16, 2014 & \\
\hline & & $1988-20 \mid 4$ & \\
\hline & & n.a. & \\
\hline \# & \multicolumn{2}{|c|}{ Searches } & Results, $n$ \\
\hline \multirow[t]{5}{*}{$\mathrm{I}$} & \multirow{5}{*}{\multicolumn{2}{|c|}{$\begin{array}{l}\text { (formoterol or eformoterol or foradil or oxis or atimos modulite or atock or perforomist or salmeterol or serevent } \\
\text { or tiotropium or spiriva or Ba } 679 \text { BR or indacaterol or onbrez or arcapta or NVA-237 or NVA237 or (NVA near/3 } \\
237 \text { ) or glycopyrronium bromide or glycopyrrolate or seebri or enurev breezhaler or aclidinium bromide or tudorza } \\
\text { pressair or eklira genuair or symbicort or advair or seretide or olodaterol or striverdi or umeclidinium or GSK5737/9 } \\
\text { or vilanterol or GW642444 or QVAI49 or relovair or zephyr or anoro ellipta): ti,ab,kw }\end{array}$}} & 4,609 \\
\hline & & & \\
\hline & & & \\
\hline & & & \\
\hline & & & \\
\hline 2 & \multicolumn{2}{|r|}{ MeSH descriptor: [Pulmonary Disease, Chronic Obstructive] explode all trees } & 2,533 \\
\hline 3 & \multirow{2}{*}{\multicolumn{2}{|c|}{$\begin{array}{l}\text { (COPD or chronic obstructive pulmonary disease or COAD or chronic obstructive airway disease or chronic } \\
\text { obstructive lung disease or chronic bronchitis or emphysema): ti,ab, } \mathrm{kw}\end{array}$}} & 10,689 \\
\hline & & & \\
\hline 4 & \multicolumn{2}{|c|}{$\# I$ and $(\# 2$ or \#3) in Trials } & 1,415 \\
\hline 5 & \multicolumn{2}{|c|}{$\# I$ and (\#2 or \#3) (in Cochrane Reviews [Reviews and Protocols]) } & 21 \\
\hline \multicolumn{4}{|c|}{$\begin{array}{l}\text { ab, kw, ti: searches performed in abstract, keyword, and title fields, respectively; n.a: not applicable } \\
\text { Line } 4 \text { corresponds to the CENTRAL database, line } 5 \text { to the CDSR database. Both results were exported. }\end{array}$} \\
\hline \multirow{5}{*}{\multicolumn{2}{|c|}{$\begin{array}{l}\text { Database } \\
\text { Platform } \\
\text { Date of search } \\
\text { Time limits } \\
\text { Filters }\end{array}$}} & & \\
\hline & & CRD (httD://www crd york. ac,uk/crdweb/) & \\
\hline & & & \\
\hline & & No time limits & \\
\hline & & n.a. & \\
\hline \# & \multicolumn{2}{|c|}{ Searches } & Results, $n$ \\
\hline 1 & \multirow{5}{*}{\multicolumn{2}{|c|}{$\begin{array}{l}\text { (formoterol or eformoterol or foradil or oxis or atimos modulite or atock or perforomist or salmeterol or serevent } \\
\text { or tiotropium or spiriva or Ba } 679 \text { BR or indacaterol or onbrez or arcapta or NVA-237 or NVA237 or (NVA and } \\
\text { "237") or glycopyrronium bromide or glycopyrrolate or seebri or enurev breezhaler or aclidinium bromide or tudorza } \\
\text { pressair or eklira genuair or symbicort or advair or seretide or olodaterol or striverdi or umeclidinium or GSK5737I9 } \\
\text { or vilanterol or GW642444 or QVAI49 or relovair or zephyr or anoro ellipta) [ANY FIELD] }\end{array}$}} & 226 \\
\hline & & & \\
\hline & & & \\
\hline & & & \\
\hline & & & \\
\hline 2 & \multirow{2}{*}{\multicolumn{2}{|c|}{$\begin{array}{l}\text { (COPD or chronic obstructive pulmonary disease or COAD or chronic obstructive airway disease or chronic } \\
\text { obstructive lung disease or chronic bronchitis or emphysema) [ANY FIELD] }\end{array}$}} & 828 \\
\hline & & & \\
\hline 3 & \multicolumn{2}{|c|}{ I and 2 in DARE } & 62 \\
\hline & applicable & & \\
\hline & & HTA & \\
\hline & & CRD (http://www.crd.york.ac.uk/crdweb/) & \\
\hline & search & April 16, 2014 & \\
\hline & mits & No time limits & \\
\hline & & n.a. & \\
\hline \# & Searche & & Results, $n$ \\
\hline 1 & (formote & r eformoterol or foradil or oxis or atimos modulite or atock or perforomist or salmeterol or serevent & 226 \\
\hline & or tiotro & or spiriva or Ba 679 BR or indacaterol or onbrez or arcapta or NVA-237 or NVA237 or (NVA and & \\
\hline & “237”) or & opyrronium bromide or glycopyrrolate or seebri or enurev breezhaler or aclidinium bromide or tudorza & \\
\hline & pressair c & lira genuair or symbicort or advair or seretide or olodaterol or striverdi or umeclidinium or GSK5737/9 & \\
\hline & or vilante & or GW642444 or QVAI49 or relovair or zephyr or anoro ellipta) [ANY FIELD] & \\
\hline 2 & (COPD c & ronic obstructive pulmonary disease or COAD or chronic obstructive airway disease or chronic & 828 \\
\hline & obstructi & ng disease or chronic bronchitis or emphysema) [ANY FIELD] & \\
\hline 3 & $\mathrm{I}$ and 2 ir & & 116 \\
\hline 4 & HTA: HT & progress and HTA published & 17 \\
\hline & gistry & clinicaltrials.gov & \\
\hline & & http://www.clinicaltrials.gov/ & \\
\hline & search & April 14,2014 & \\
\hline & strategy & $\begin{array}{l}\text { COPD OR COAD OR "Chronic obstructive pulmonary disease" OR "Chronic obstructive lung disease" } \\
\text { obstructive airway disease" OR "chronic bronchitis" OR "emphysema"| Phase } 2,3,4\end{array}$ & chronic \\
\hline & & 949 & \\
\hline
\end{tabular}


Table SI (Continued)

\begin{tabular}{|c|c|}
\hline Trial registry & WHO International Clinical Trials Registry Platform (ICTRP) \\
\hline URL & http://apps.who.int/trialsearch/AdvSearch.aspx \\
\hline Date of search & April 14, 2014 \\
\hline Search strategy & $\begin{array}{l}\text { COPD OR chronic obstructive pulmonary disease OR COAD OR chronic obstructive airway disease OR chronic } \\
\text { obstructive lung disease OR chronic bronchitis OR emphysema }\end{array}$ \\
\hline Results & 3,852 records for 2,922 trials found* \\
\hline \multicolumn{2}{|c|}{$\begin{array}{l}\text { *The WHO ICTRP imports records from several registries. Trials are sometimes recorc } \\
\text { a secondary identification number. The search portal uses this secondary identification } \\
\text { results. } \\
\text { All results were reported in an excel database. However, WHO ICTRP also collects da } \\
\text { criterion, trials listed on national non-Caucasian registries were excluded for population } \\
\text { Registry - India; Iranian Registry of Clinical Trials; Japan Primary Registries Network). }\end{array}$} \\
\hline $\begin{array}{l}\text { Trial registry } \\
\text { URL } \\
\text { Date of search } \\
\text { Search strategy }\end{array}$ & $\begin{array}{l}\text { Current controlled trials } \\
\text { http://www.controlled-trials.com/ } \\
\text { April I5, } 2014 \\
\text { (COPD or chronic obstructive pulmonary disease or COAD or chronic obstructive airway disease or chronic obstructive } \\
\text { lung disease or chronic bronchitis or emphysema) in Databases: ISRCTN Register (International) - copy of ISRCTN } \\
\text { Register; Action Medical Research (UK) - subset from ISRCTN Register; The Wellcome Trust (UK) - subset from } \\
\text { ISRCTN Register; UK trials (UK) - subset from ISRCTN Register, UK trials only } \\
87\end{array}$ \\
\hline \multicolumn{2}{|c|}{ ClinicalTrials.gov was removed from the list of resources searched in this aggregated database, as clinicaltrials.gov was searched directly in a separate search. } \\
\hline $\begin{array}{l}\text { Trial registry } \\
\text { URL } \\
\text { Date of search } \\
\text { Search strategy }\end{array}$ & $\begin{array}{l}\text { EU Clinical Trials Register (EU-CTR) } \\
\text { www.clinicaltrialsregister.eu } \\
\text { April I5, } 2014 \\
\text { (COPD OR chronic obstructive pulmonary disease OR COAD OR chronic obstructive airway disease OR chronic } \\
\text { obstructive lung disease OR chronic bronchitis OR emphysema) AND (Phase II OR Phase III or Phase IV [Select trial } \\
\text { phase]) }\end{array}$ \\
\hline Results & 307 \\
\hline $\begin{array}{l}\text { Trial registry } \\
\text { URL } \\
\text { Date of search } \\
\text { Search strategy }\end{array}$ & $\begin{array}{l}\text { Klinische Prüfungen PharmNet.Bund } \\
\text { http://www.pharmnet-bund.de/dynamic/de/klinische-pruefungen/index.htm } \\
\text { April I5, 20I4 } \\
\text { COPD in Textfelder AND Limit to Phase II or Phase III or Phase IV [Trial phase] AND Limit to therapy or safety or } \\
\text { efficacy [Trial scope] AND Limit to patients [Trial population] }\end{array}$ \\
\hline Results & 320 \\
\hline Trial registry & International Prospective Register of Systematic Reviews (PROSPERO) \\
\hline URL & http://www.crd.york.ac.uk/NIHR_PROSPERO/ \\
\hline Date of search & April 18,2014 \\
\hline \multirow[t]{4}{*}{ Search strategy } & Separate searches for: COPD [ALL FIELDS] or chronic obstructive pulmonary disease [ALL FIELDS] or COAD \\
\hline & [ALL FIELDS] or chronic obstructive airway disease [ALL FIELDS] or chronic obstructive lung disease [ALL FIELDS] \\
\hline & or chronic bronchitis [ALL FIELDS] or Emphysema [ALL FIELDS] \\
\hline & Review status: Any review status \\
\hline Results & 122 \\
\hline \multicolumn{2}{|c|}{ *Please note that search terms have to be searched for manually each and every one of them and then de-duplicated at the end. } \\
\hline Trial registry & National Institute for Health Research - Health Technology Assessment (NIHR HTA) \\
\hline URL & http://www.nets.nihr.ac.uk/projects \\
\hline Date of search & April 18,2014 \\
\hline Search strategy & COPD [Keywords] and HTA [programme] in the advanced search \\
\hline Results & 13 \\
\hline
\end{tabular}

Abbreviations: CDSR, Cochrane Database of Systematic Review; CENTRAL, Cochrane Central Register of Controlled Trials; CSR, clinical study report; DARE, Database of Abstracts of Reviews of Effects; EU-CTR, EU Clinical Trials Register; HTA, Health Technology Assessment; ITC, indirect treatment comparison; PROSPERO, International Prospective Register of Systematic Reviews; SLR, systematic literature review; WHO ICTRP, World Health Organization International Clinical Trials Registry Platform. 
Table S2 Participants, interventions, comparisons, outcomes, and study design (PICOS) criteria

\begin{tabular}{|c|c|c|c|}
\hline Criteria & & Inclusion & Exclusion \\
\hline \multirow[t]{3}{*}{ Study design } & $\begin{array}{l}\text { Abstract } \\
\text { selection }\end{array}$ & Randomized controlled trials & $\begin{array}{l}\text { Cross-over studies; post hoc or retrospective analyses; cost- } \\
\text { effectiveness analyses; observational studies; reviews or meta-analyses; } \\
\text { methodology studies or protocols; } \mathrm{N} \text { of I trials (sample size of one } \\
\text { patient); studies lasting less than } 2 \text { weeks }\end{array}$ \\
\hline & Full-text & & Studies where patients were required to spend time in a sleep \\
\hline & selection & & laboratory \\
\hline \multirow{13}{*}{$\begin{array}{l}\text { Treatment/ } \\
\text { intervention }\end{array}$} & Abstract & Umeclidinium; tiotropium; aclidinium; & Studies comparing only double or triple therapies (ie, LABA, LAMA, ICS \\
\hline & selection & $\begin{array}{l}\text { glycopyrronium; indacaterol; salmeterol; } \\
\text { olodaterol; formoterol }\end{array}$ & $\begin{array}{l}\text { as fixed or open combinations) to each other or to placebo; } \beta \text {-agonists } \\
\text { (bambuterol; fenoterol; tulobuterol); short-acting anticholinergics }\end{array}$ \\
\hline & & & (Ipratropium; Oxitropium); Methylxanthines (theophylline); Inhaled \\
\hline & & & glucocorticosteroids (beclomethasone; budesonide; fluticasone); \\
\hline & & & Leukotriene receptor antagonists (montelukast); combinations of \\
\hline & & & long-acting anticholinergics or LABAs with an ICS; formoterol plus \\
\hline & & & budesonide or fluticasone plus salmeterol that are administered \\
\hline & & & separately; COPD drugs in development or targeting other pathways \\
\hline & & & (roflumilast; polyvalent mechanical bacterial lysate; lipopolysaccharide); \\
\hline & & & all other pharmaceutical interventions not treating COPD (enoxaparin \\
\hline & & & sodium); non-pharmaceutical interventions such as pulmonary \\
\hline & & & rehabilitation \\
\hline & Full-text & Umeclidinium; tiotropium; aclidinium; & Studies of arformoterol (the $(R, R)$ isomer of formoterol) \\
\hline
\end{tabular}

selection glycopyrronium; indacaterol; salmeterol; olodaterol; formoterol; administered using any inhalation device

Comparator Abstract Studies that compare treatments of interest and (above) with placebo or to each other full-text selection

Population Abstract Patients with COPD as defined by GOLD and guidelines (ie, airflow limitation that is not fully full-text reversible); studies that include asthma patients selection and COPD patients and report data for COPD patients separately; adults; studies that include adults and children and report data for adults separately

Outcomes Abstract Report results for one of the following outcomes and (for all treatments) at any time point $\geq 10$ weeks: full-text trough $\mathrm{FEV}_{1}$; post-bronchodilator $\mathrm{FEV}_{\mathrm{l}}$; SGRQ selection total score; proportion of patients with an improvement of at least 4 units in SGRQ total score; TDI focal score; proportion of patients with an improvement of at least I unit in TDI score; rate of exacerbations per patientyear over the trial period across definitions; proportion of patients experiencing at least one exacerbation (across definitions) at the end of the study; rescue medication (eg, short-acting $\beta_{2}$-agonists, inhaled corticosteroids) allowed; adverse event rates at the end of the study; serious adverse event rates at the end of the study; withdrawals due to adverse event rates at the end of the study; hospitalization due to adverse event rates at the end of the study; mortality rates at the end of the study
Studies that only compare treatments of interest to treatment not of interest (above) (ie, excluding placebo comparison); studies that only include the treatments of interest in combination with treatments not of interest (ie, prednisolone + formoterol); studies that only include the partial combinations of treatments of interest (ie, Tiotropium + ICS) Studies with only healthy patients without COPD; studies with patients who have reversible airway or obstructive lung disease; studies with only patients with asthma; studies that include asthma patients and COPD patients but do not report data for COPD patients separately; studies with only patients who have alpha-I-antitrypsin-deficiencyrelated COPD; studies that include only children; studies that include adults and children but do not report data for adults separately Only report the following outcomes (without any outcomes of interest): bioactivity outcomes or biomarkers of inflammation; lung mucociliary clearance; arterial blood gases or degree of pulmonary hyper-inflation; plethysmography and oscillometry; nocturnal hypoxemia; quality of life in EuroQoL; reporting outcomes at time points $<10$ weeks

Abbreviations: FEV , forced expiratory volume in I second; ICS, inhaled corticosteroid; LABA, long-acting $\beta$-2 agonist; LAMA, long-acting muscarinic antagonist; SGRQ, St George's Respiratory Questionnaire; TDI, transitional dyspnea index. 
Table S3 Data extraction

\begin{tabular}{|c|c|}
\hline Parameters extracted from studies & \\
\hline \multirow[t]{11}{*}{ Study characteristics } & Author \\
\hline & Publication year \\
\hline & Compared interventions including drug name, dose, and administration frequency \\
\hline & Number of randomized patients \\
\hline & Trial design \\
\hline & Centers and countries \\
\hline & Inclusion criteria \\
\hline & Background treatments \\
\hline & Trial duration \\
\hline & ICS allowed (as background) \\
\hline & LABAs allowed (as background) \\
\hline \multirow[t]{14}{*}{ Baseline patient characteristics } & Proportion of males \\
\hline & Age (SD) \\
\hline & Proportion of current smokers \\
\hline & Proportion of patients with severe or very severe COPD \\
\hline & Proportion of patients using ICS \\
\hline & Duration of COPD (SD) \\
\hline & Smoking history pack-years (SD) \\
\hline & FEV,$\%$ predicted (SD) \\
\hline & $\mathrm{FEV}_{\mathrm{I}} / \mathrm{FVC}$ percentage (SD) \\
\hline & $\mathrm{FVC}$ mean (SD) \\
\hline & BDI mean \\
\hline & Number of exacerbations in previous year \\
\hline & Percentage reversibility \\
\hline & Ethnicity \\
\hline \multirow[t]{4}{*}{ Outcomes at 12 (8-16 weeks) and 24 weeks (20-28 weeks) } & Trough FEV, \\
\hline & TDI focal score \\
\hline & SGRQ total score \\
\hline & Rescue medication use (number of puffs per day) \\
\hline
\end{tabular}

Abbreviations: BDI, Baseline Dyspnea Index; FEV , forced expiratory volume in I second; FVC, forced vital capacity; ICS, inhaled corticosteroids; LABA, long-acting $\beta$-2 agonist; SD, standard deviation; SGRQ, St George's Respiratory Questionnaire; TDI, transitional dyspnea index.

Table S4 Risk of bias assessment for the included studies

\begin{tabular}{|c|c|c|c|c|c|c|c|}
\hline \multirow[t]{2}{*}{$\overline{\text { Study }}$} & \multirow{2}{*}{$\begin{array}{l}\text { Adequate } \\
\text { generation of } \\
\text { randomization } \\
\text { sequence }\end{array}$} & \multirow{2}{*}{$\begin{array}{l}\text { Adequate } \\
\text { allocation } \\
\text { concealment }\end{array}$} & \multicolumn{2}{|l|}{ Blinding } & \multirow{2}{*}{$\begin{array}{l}\text { Result } \\
\text { independent } \\
\text { reporting }\end{array}$} & \multirow{2}{*}{$\begin{array}{l}\text { No other } \\
\text { aspects that } \\
\text { increase the } \\
\text { risk of bias }\end{array}$} & \multirow{2}{*}{$\begin{array}{l}\text { Risk of } \\
\text { bias }\end{array}$} \\
\hline & & & Patients & Caregivers & & & \\
\hline Chan et al,' SAFE,, ${ }^{2,3}$ SAFE-Portugal ${ }^{4}$ & Unclear & Yes & Yes & Yes & Yes & Yes & Low \\
\hline TIPHON ${ }^{5}$ & Yes & Yes & Yes & Yes & Yes & Yes & Low \\
\hline UPLIFT ${ }^{6,7}$ & Yes & Yes & Yes & Yes & Yes & Yes & Low \\
\hline Niewoehner et $\mathrm{al}^{8}$ & Yes & Yes & Yes & Yes & Yes & Yes & Low \\
\hline Brusasco et $\mathrm{al}^{9}$ & Unclear & Yes & Yes & Yes & Yes & Yes & Low \\
\hline Donohue et al ${ }^{10}$ & Unclear & Yes & Yes & Yes & Yes & Yes & Low \\
\hline Casaburi et al" & Unclear & Yes & Yes & Yes & Yes & Yes & Low \\
\hline Donohue et al' ${ }^{12}$ & Unclear & No & No & No & Yes & Yes & High \\
\hline SHINE ${ }^{13}$ & Yes & No & No & No & Yes & Yes & High \\
\hline GLOWI ${ }^{14}$ & Unclear & Yes & Yes & Yes & Yes & Yes & Low \\
\hline GLOW215 & Unclear & Unclear & Yes & Yes & Yes & Yes & Low \\
\hline
\end{tabular}


Table S4 (Continued)

\begin{tabular}{|c|c|c|c|c|c|c|c|}
\hline \multirow[t]{2}{*}{ Study } & \multirow{2}{*}{$\begin{array}{l}\text { Adequate } \\
\text { generation of } \\
\text { randomization } \\
\text { sequence }\end{array}$} & \multirow{2}{*}{$\begin{array}{l}\text { Adequate } \\
\text { allocation } \\
\text { concealment }\end{array}$} & \multicolumn{2}{|l|}{ Blinding } & \multirow{2}{*}{$\begin{array}{l}\text { Result } \\
\text { independent } \\
\text { reporting }\end{array}$} & \multirow{2}{*}{$\begin{array}{l}\text { No other } \\
\text { aspects that } \\
\text { increase the } \\
\text { risk of bias }\end{array}$} & \multirow{2}{*}{$\begin{array}{l}\text { Risk of } \\
\text { bias }\end{array}$} \\
\hline & & & Patients & Caregivers & & & \\
\hline Verkindre et al $^{16}$ & Unclear & Yes & Yes & Yes & Yes & Yes & Low \\
\hline Casaburi et al ${ }^{17}$ & Unclear & Yes & Yes & Yes & Yes & Yes & Low \\
\hline Covelli et al $^{18}$ & Unclear & Yes & Yes & Yes & Yes & Yes & Low \\
\hline Garcia et al ${ }^{19}$ & Unclear & Yes & Yes & Yes & Yes & Unclear & Low \\
\hline Moita et $\mathrm{al}^{20}$ & Unclear & Yes & Yes & Yes & Yes & Yes & Low \\
\hline Vogelmeier et $\mathrm{al}^{21}$ & Unclear & No & No & No & Yes & Yes & High \\
\hline ACCORD COPD $1^{22}$ & Unclear & Yes & Yes & Yes & Yes & Yes & Low \\
\hline ACCORD COPD $\|^{23}$ & No & Yes & Yes & Yes & Yes & Yes & High \\
\hline ATTAIN ${ }^{24}$ & Unclear & Yes & Yes & Yes & Yes & Yes & Low \\
\hline DB2 I I $3373,{ }^{25}$ Donohue et a $\left.\right|^{26}$ & Yes & Yes & Yes & Yes & Yes & Yes & Low \\
\hline AC4II $5408^{27}$ & Yes & Yes & Yes & Yes & Yes & Yes & Low \\
\hline SPARK $^{28}$ & Yes & No & No & No & No & Yes & High \\
\hline GLOW5 $5^{29}$ & Unclear & Yes & Yes & Yes & Yes & Yes & Low \\
\hline
\end{tabular}

Notes: Unclear randomization means that it was mentioned that the study was randomized (and in most cases even with which ratio, eg, I:I); however, it was not specified how the randomization was generated (eg, by computer). SPARK, ${ }^{28}$ SHINE, ${ }^{13}$ Vogelmeier et al, ${ }^{21}$ and Donohue et al ${ }^{12}$ included tiotropium $18 \mu g$ as an open-label arm and were categorized as having a high risk of bias. ACCORD COPD $11^{23}$ had imbalances in baseline characteristics despite randomization (for FEV , and the percentage of patients with GOLD stage II and III); due to these issues in randomization ACCORD COPD II was categorized as having a high risk of bias.

Abbreviation: $\mathrm{FEV}_{1}$, forced expiratory volume in I second.

Table S5 Individual study results for trough SGRQ total scores, TDI focal scores, and rescue medication use

\begin{tabular}{|c|c|c|c|c|}
\hline Treatment & References & $\begin{array}{l}\text { SGRQ total score } \\
\text { at I } 2 \text { weeks, mean } \\
\text { difference in change } \\
\text { from baseline (SE) }\end{array}$ & $\begin{array}{l}\text { TDI focal score } \\
\text { at I } 2 \text { weeks, } \\
\text { mean difference } \\
\text { (SE) }\end{array}$ & $\begin{array}{l}\text { Rescue medication puffs } \\
\text { per day at } 12 \text { weeks, mean } \\
\text { difference in change from } \\
\text { baseline (SE) }\end{array}$ \\
\hline Tiotropium & Donohue et al ${ }^{\prime 2}$ & $-1.10(0.87)$ & $0.80(0.22)$ & - \\
\hline \multirow[t]{5}{*}{ versus placebo } & SHINE ${ }^{13}$ & - & $0.59(0.27)$ & - \\
\hline & Verkindre et al $^{16}$ & $-6.50(2.90)$ & I.30 (0.89) & $-0.13(0.25)$ \\
\hline & GLOW215 & $-2.84(0.97)$ & $0.26(0.30)$ & - \\
\hline & $\mathrm{TIPHON}^{5}$ & $-3.59(1.22)$ & - & - \\
\hline & Casaburi et al"' & - & $0.95(0.18)$ & - \\
\hline Aclidinium & ATTAIN $^{24}$ & $-4.09(1.02)$ & $0.90(0.28)$ & - \\
\hline \multirow[t]{2}{*}{ versus placebo } & ACCORD COPD $I^{22}$ & $-2.50(0.89)$ & $\mathrm{I} .00(0.25)$ & $-0.9\left(0.2 \mathrm{I}^{\mathrm{a}}\right)$ \\
\hline & ACCORD COPD $\|^{23}$ & $-1.10(1.18)$ & $\mathrm{I} .00(0.28)$ & $-0.31\left(0.22^{\mathrm{a}}\right)$ \\
\hline Glycopyrronium & SHINE ${ }^{13}$ & - & $0.82(0.27)$ & - \\
\hline versus placebo & GLOW215 & $-3.17(0.84)$ & $0.60(0.27)$ & - \\
\hline Glycopyrronium & SPARK ${ }^{28}$ & $-0.50(0.88)$ & - & - \\
\hline versus & GLOW5 $5^{29}$ & $0.65(0.94)$ & $-0.188(0.22)$ & $0(0.15)$ \\
\hline \multicolumn{5}{|l|}{ tiotropium } \\
\hline Umeclidinium & DB211 $3373^{25}$ & $-3.59(1.06)$ & $0.90(0.23)$ & $-0.34(0.25)$ \\
\hline versus placebo & AC4II5408 27 & $-7.90(2.19)$ & $\mathrm{I} .00(0.5 \mathrm{I})$ & $-0.70(0.31)$ \\
\hline
\end{tabular}

Notes: amputed value; -, no data available.

Abbreviations: SE, standard error; SGRQ, St George's Respiratory Questionnaire; TDI, transitional dyspnea index. 
Table S6 Differences in intervention versus the comparator for change for SGRQ total scores, TDI focal scores, and rescue medication use at 12 weeks ( $95 \% \mathrm{Crl}$ and probability of the intervention being better than the comparator)

\begin{tabular}{|c|c|c|c|c|c|}
\hline \multirow[t]{2}{*}{ Intervention } & \multicolumn{5}{|c|}{ Comparator } \\
\hline & & Placebo & Tiotropium & Aclidinium & Glycopyrronium \\
\hline \multicolumn{6}{|c|}{ SGRQ total score (difference in change from baseline, units) at 12 weeks } \\
\hline \multirow[t]{3}{*}{ Tiotropium } & Estimate & -2.49 & & & \\
\hline & $95 \% \mathrm{Crl}$ & -3.56 to $-1.4 \mid$ & & & \\
\hline & $P$ (better) & $>99 \%$ & & & \\
\hline \multirow[t]{3}{*}{ Aclidinium } & Estimate & -2.68 & -0.19 & & \\
\hline & $95 \% \mathrm{Crl}$ & -3.82 to -1.54 & -1.76 to 1.36 & & \\
\hline & $P$ (better) & $>99 \%$ & $60 \%$ & & \\
\hline \multirow[t]{3}{*}{ Glycopyrronium } & Estimate & -2.74 & -0.25 & -0.06 & \\
\hline & $95 \% \mathrm{Crl}$ & -3.91 to -1.56 & -1.07 to 0.56 & -1.70 to 1.58 & \\
\hline & $P$ (better) & $>99 \%$ & $73 \%$ & $53 \%$ & \\
\hline \multirow[t]{3}{*}{ Umeclidinium } & Estimate & -4.41 & -1.92 & -1.73 & -1.67 \\
\hline & $95 \% \mathrm{Crl}$ & -6.27 to -2.53 & -4.08 to 0.24 & -3.92 to 0.47 & -3.88 to 0.54 \\
\hline & $P$ (better) & $>99 \%$ & $96 \%$ & $94 \%$ & $93 \%$ \\
\hline \multicolumn{6}{|c|}{ TDI focal score (difference versus comparator) at 12 weeks } \\
\hline \multirow[t]{3}{*}{ Tiotropium } & Estimate & 0.75 & & & \\
\hline & $95 \% \mathrm{Crl}$ & $0.53-0.97$ & & & \\
\hline & $P$ (better) & $>99 \%$ & & & \\
\hline \multirow[t]{3}{*}{ Aclidinium } & Estimate & 0.97 & 0.21 & & \\
\hline & $95 \% \mathrm{Crl}$ & $0.66-1.27$ & -0.16 to 0.59 & & \\
\hline & $P$ (better) & $>99 \%$ & $87 \%$ & & \\
\hline \multirow[t]{3}{*}{ Glycopyrronium } & Estimate & 0.94 & 0.18 & -0.03 & \\
\hline & $95 \% \mathrm{Crl}$ & $0.69-1.18$ & 0.04 to 0.33 & -0.42 to 0.36 & \\
\hline & $P$ (better) & $>99 \%$ & $>99 \%$ & $44 \%$ & \\
\hline \multirow[t]{3}{*}{ Umeclidinium } & Estimate & 0.92 & 0.16 & -0.05 & -0.02 \\
\hline & $95 \% \mathrm{Crl}$ & $0.5 \mathrm{I}-1.33$ & -0.30 to 0.63 & -0.56 to 0.46 & -0.50 to 0.46 \\
\hline & $P$ (better) & $>99 \%$ & $75 \%$ & $43 \%$ & $47 \%$ \\
\hline \multicolumn{6}{|c|}{ Rescue medication use (difference versus comparator) at I 2 weeks } \\
\hline \multirow[t]{3}{*}{ Tiotropium } & Estimate & -0.13 & & & \\
\hline & $95 \% \mathrm{Crl}$ & -0.62 to 0.36 & & & \\
\hline & $P$ (better) & 0.70 & & & \\
\hline \multirow[t]{3}{*}{ Glycopyrronium } & Estimate & -0.13 & 0.00 & & \\
\hline & $95 \% \mathrm{Crl}$ & -0.70 to 0.44 & -0.29 to 0.29 & & \\
\hline & $P$ (better) & 0.68 & $50 \%$ & & \\
\hline \multirow[t]{3}{*}{ Umeclidinium } & Estimate & -0.48 & -0.35 & & -0.35 \\
\hline & $95 \% \mathrm{Crl}$ & -0.86 to -0.10 & -0.97 to 0.27 & & -1.03 to 0.34 \\
\hline & $P$ (better) & $>99 \%$ & $86 \%$ & & $84 \%$ \\
\hline
\end{tabular}

Abbreviations: $\mathrm{Crl}$, credible interval; FEV , forced expiratory volume in I second; SGRQ, St George's Respiratory Questionnaire; TDI, transitional dyspnea index.

\section{References}

1. Chan CKN, Maltais F, Sigouin C, Haddon JM, Ford GT. A randomized controlled trial to assess the efficacy of tiotropium in Canadian patients with chronic obstructive pulmonary disease. Can Respir J. 2007;14:465-472.

2. Spiriva Assessment of FEV1 (SAFE). The effect of inhaled tiotropium bromide (18 mcg once daily) on the change in FEV1 during long-term treatment in patients with COPD. A one-year parallel group, double-blind, randomised, placebo-controlled study. Boehringer Ingelheim Clinical Trial Register. NLM: NCT00277264. 2005. Available from: http:// trials.boehringer-ingelheim.com/content/dam/internet/opu/clinicaltrial/ com_EN/results/205/205.259_U05-3345.pdf. Accessed October 19, 2015.

3. Spiriva ${ }^{\circledR}$ Assessment of FEV1 (SAFE). Boehringer Ingelheim. 2013. NLM identifier: NCT00277264. Available from: http://trials.boehringer-ingelheim.com/content/dam/internet/opu/clinicaltrial/com_EN/ results/205/205.259_U05-3345.pdf. Accessed October 19, 2015.
4. Spiriva (Tiotropium Bromide) Assessment of FEV1 - (SAFE-Portugal). Boehringer Ingelheim. 2013. NLM identifier: NCT00239408. Available from: http://trials.boehringer-ingelheim.com/content/dam/internet/opu/ clinicaltrial/com_EN/results/205/205.282_U06-2124.pdf. Accessed October 19, 2015.

5. Tonnel AB, Perez T, Grosbois JM, Verkindre C, Bravo ML, Brun M. Effect of tiotropium on health-related quality of life as a primary efficacy endpoint in COPD. Int J Chron Obstruct Pulmon Dis. 2008;3: 301-310.

6. Tashkin DP, Celli B, Senn S, et al. A 4-year trial of tiotropium in chronic obstructive pulmonary disease. N Engl J Med. 2008;359:1543-1554.

7. Evaluation of the long-term effects of spiriva on lung function in COPD patients. Boehringer Ingelheim. 2005. NLM identifier: NCT00144339.

8. Niewoehner DE, Rice K, Cote C, et al. Prevention of exacerbations of chronic obstructive pulmonary disease with tiotropium, a once-daily inhaled anticholinergic bronchodilator: a randomized trial. Ann Intern Med. 2005;143:317-326. 
9. Brusasco V, Hodder R, Miravitlles M, Korducki L, Towse L, Kesten S. Health outcomes following treatment for six months with once daily tiotropium compared with twice daily salmeterol in patients with COPD. Thorax. 2003;58:399-404.

10. Donohue JF, van Noord JA, Bateman ED, et al. A 6-month, placebo-controlled study comparing lung function and health status changes in COPD patients treated with tiotropium or salmeterol. Chest. 2002;122:47-55.

11. Casaburi R, Mahler DA, Jones PW, et al. A long-term evaluation of once-daily inhaled tiotropium in chronic obstructive pulmonary disease. Eur Respir J. 2002;19:217-224.

12. Donohue JF, Fogarty C, Lotvall J, et al. Once-daily bronchodilators for chronic obstructive pulmonary disease indacaterol versus tiotropium. Am J Respir Crit Care Med. 2010;182:155-162.

13. Bateman ED, Ferguson GT, Barnes N, et al. Dual bronchodilation with QVA149 versus single bronchodilator therapy: the SHINE study. Eur Respir J. 2013;42:1484-1494.

14. D’Urzo A, Ferguson GT, van Noord JA, et al. Efficacy and safety of once-daily NVA237 in patients with moderate-to-severe COPD: the GLOW1 trial. Respir Res. 2011;12:156.

15. Kerwin E, Hebert J, Gallagher N, et al. Efficacy and safety of NVA237 versus placebo and tiotropium in patients with COPD: the GLOW2 study. Eur Respir J. 2012;40:1106-1114.

16. Verkindre C, Bart F, Aguilaniu B, et al. The effect of tiotropium on hyperinflation and exercise capacity in chronic obstructive pulmonary disease. Respiration. 2006;73:420-427.

17. Casaburi R, Briggs DD, Donohue JF, Serby CW, Menjoge SS, Witek TJ. The spirometric efficacy of once-daily dosing with tiotropium in stable COPD - a 13-week multicenter trial. Chest. 2000;118:1294-1302.

18. Covelli H, Bhattacharya S, Cassino C, Conoscenti C, Kesten S. Absence of electrocardiographic findings and improved function with once-daily tiotropium in patients with chronic obstructive pulmonary disease. Pharmacotherapy. 2005;25:1708-1718.

19. Garcia RF. A randomised, double-blind, placebo-controlled, 12 weeks trial to evaluate the effect of Tiotropium Inhalation Capsules on the magnitude of exercise, measured using an accelerometer, in patients with Chronic Obstructive Pulmonary Disease (COPD). Boehringer Ingelheim Trial Results. 2007. NLM Identifier: NCT00144326. Available from: http://rials.boehringer-ingelheim.com/content/dam/internet/ opu/clinicaltrial/com_EN/results/205/205.269.pdf. Accessed October $19,2015$.
20. Moita J, Barbara C, Cardoso J, et al. Tiotropium improves FEV1 in patients with COPD irrespective of smoking status. Pulm Pharmacol Ther. 2008;21:146-151.

21. Vogelmeier C, Kardos P, Harari S, Gans SJM, Stenglein S, Thirlwell J. Formoterol mono- and combination therapy with tiotropium in patients with COPD: a 6-month study. Respir Med. 2008;102:1511-1520.

22. Kerwin EM, D’Urzo AD, Gelb AF, Lakkis H, Garcia GE, Caracta CF. Efficacy and safety of a 12-week treatment with twice-daily aclidinium bromide in COPD patients (ACCORD COPD I). COPD. 2012;9:90-101.

23. Rennard SI, Scanlon PD, Ferguson GT, et al. ACCORD COPD II: a randomized clinical trial to evaluate the 12-week efficacy and safety of twice-daily aclidinium bromide in chronic obstructive pulmonary disease patients. Clin Drug Invest. 2013;33:893-904.

24. Jones PW, Singh D, Bateman ED, et al. Efficacy and safety of twicedaily aclidinium bromide in COPD patients: the ATTAIN study. Eur Respir J. 2012;40:830-836.

25. GlaxoSmithKline. Clinical Study Report - DB2113373. 2013.

26. Donohue JF, Maleki-Yazdi MR, Kilbride S, Mehta R, Kalberg C, Church A. Efficacy and safety of once-daily umeclidinium/vilanterol 62.5/25 mcg in COPD. Respir Med. 2013;107:1538-1546.

27. GlaxoSmithKline. Clinical Study Report - AC4115408. 2013.

28. Wedzicha JA, Decramer M, Ficker JH, et al. Analysis of chronic obstructive pulmonary disease exacerbations with the dual bronchodilator QVA149 compared with glycopyrronium and tiotropium (SPARK): a randomised, double-blind, parallel-group study. Lancet Respir Med. 2013;1:199-209.

29. Chapman KR, Beeh KM, Beier J, et al. A blinded evaluation of the efficacy and safety of glycopyrronium, a once-daily long-acting muscarinic antagonist, versus tiotropium, in patients with COPD: the GLOW5 study. BMC Pulm Med. 2014;14:4.
International Journal of COPD

\section{Publish your work in this journal}

The International Journal of COPD is an international, peer-reviewed journal of therapeutics and pharmacology focusing on concise rapid reporting of clinical studies and reviews in COPD. Special focus is given to the pathophysiological processes underlying the disease, intervention programs, patient focused education, and self management protocols.

\section{Dovepress}

This journal is indexed on PubMed Central, MedLine and CAS. The manuscript management system is completely online and includes a very quick and fair peer-review system, which is all easy to use. Visit http://www.dovepress.com/testimonials.php to read real quotes from published authors. 